Araștırma Makalesi - Gönderim Tarihi: 16 Eylül 2019 - Kabul Tarihi: 31 Aralık 2019

\title{
Gazetecilik Eğitimi Sonrası Mesleki Yönelim: 2010-2017 Ege Üniversitesi Gazetecilik Bölümü Mezunları Üzerine Bir Araștırma
}

\section{Yurdagül Bezirgan ARAR'}

\author{
Öz
}

Türkiye'de iletişim eğitimi veren üniversitelerin gazetecilik bölümlerinden her yıl çok sayıda öğrenci mezun olmaktadır. Ancak Türkiye'de gazetecilik yapmanın önündeki politik, ekonomik, sosyal ve mesleki güçlüklerin yanı sıra, kişisel nedenler ve kariyer beklentileri mesleğe yönelim konusunda belirleyici olmakta ve gazetecilik mezunları çok çeşitli alanlarda istihdam olabilmektedirler. Gazetecilik dışı mesleki alanlara yönelim, iradi tercihlerden daha ziyade zorunluluktan kaynaklanmaktadır. Bu yöndeki kişisel bir gözlemden yola çıkılan bu araştırmanın amacı, iletişim fakültelerinin gazetecilik bölümlerinde lisans eğitimi alan öğrencilerin mezuniyet sonrası mesleki yönelimlerini ve bu yönelimdeki çeşitliliğin dağılımını ölçümlemek; eğitimi alınan lisans programıyla, mesleki yönelim arasındaki tutarlıık ya da tutarsızlık şeklinde kendini gösteren ilişkinin dinamiklerini ortaya koymak; gazetecilik mezunlarının mesleki yönelimlerini tayin eden faktörleri belirlemek ve söz konusu yönelimde gazetecilik eğitiminin olumlu/ olumsuz etkilerini ampirik verilere dayanarak açıklamaktır. Mezunların gazetecilik eğitimine ve mesleğe ilişkin tutumlarını ölçmek, araştırmanın amacına ilişkin bir diğer boyutu oluşturmaktadır. Bu doğrultuda, Ege Üniversitesi İletişim Fakültesi Gazetecilik Bölümü’nde lisans gazetecilik eğitimini tamamlayarak, 2010-2017 yılları arasında mezun olan öğrenciler örneğinde bir alan araştırması gerçekleştirilmiştir. Araştırmada veri toplama aracı olarak, açık/kapalı uçlu ve tutum ölçmeye yönelik 26 sorudan oluşan ve araştırmacı tarafından geliştirilen bir soru formu kullanılmıştır. Veriler SPSS'te analiz edilmiştir. Araştırmanın öne çıkan bazı bulguları şunlardır: Gazetecilik formasyonu bilinçli bir tercih olmakla birlikte, eğitim sürecinde ve mezuniyet sonrasında bu hevesi kıran dinamikler devreye girmektedir. Mezunlar, "ideal gazetecilik", "gazetecilik onurlu bir meslektir" gibi zihinsel tasavvurlarını muhafaza etseler de, Türkiye'deki gazeteciliği sorgulamakta ve "tehlikeli" bir meslek olarak görmektedirler. Gazeteciliği yurt dışında yapmayı tercih etmektedirler. Mesleki yönelimi gazetecilik olanların çoğu yerel oluşumlarda ve muhabir statüsünde çalışmaktadırlar. Ancak ekonomik gerekçelerle uzun süre gazetecilik yapmayı düşünmemektedirler. Gazetecilik dışı alanlara mesleki yönelimi ise ekonomik gerekçeler ve yine Türkiye'deki gazeteciliğin olumsuz koşulları belirlemektedir. Gazetecilik dışı alanlara yönelenlerin çoğu özel sektörde işçi olarak çalışmaktadır. Bulgular, mezuniyet sonrası işsizlik gerçeğini desteklemektedir.

Anahtar Kelimeler: Gazetecilik eğitimi, gazetecilik mezunları, mesleki yönelim, gazeteci istihdamı

Atıf: Arar, Y. B. (2019). “Gazetecilik Eğitimi Sonrası Mesleki Yönelim: 2010-2017 Ege Üniversitesi Gazetecilik Bölümü Mezunları Üzerine Bir Araștırma”. Akdeniz Üniversitesi İletișim Fakültesi Dergisi, (AKiL) Aralık (32), s. $734-768$

1 Doç. Dr., Ege Üniversitesi İletişim Fakültesi Gazetecilik Bölümü, e-mail: yurdagulakademik@gmail.com, Orcid Numarası:0000-0002-9783-9923 


\title{
Professional Orientation After Journalism Education: A Research On Ege University Journalism Department Graduates Between 2010-2017
}

\begin{abstract}
Many students graduate from journalism departments of universities which give communication education in Turkey each year. But, beside the political, economical, social and professional difficulties of performing journalism in Turkey, personal causes and career expectations determine professional orientation and journalism graduates can be employed in a wide range of fields. The tendency towards non-journalistic professional fields is due to greater necessity than to voluntary preferences. The aim of this research, which was initiated by a personal observation, is to survey professional orientations of journalism graduates; to reveal the dynamics of the relationship that manifests itself as consistency or inconsistency between the undergraduate program and the professional orientation; to identify the factors that determine the professional orientation of journalism graduates and to explain the positive/negative effects of journalism education based on empirical evidences. Another purpose of the study is to measure graduates' attitudes toward journalistic education and the profession. In this direction, a field research was held among graduates (2010-2017) of Ege University Faculty of Communication. For data collection, an original questionnaire was developed by the researcher. The survey is comprised of 26 questions which aim to dissect attitude meausurement by open/close-ended questions. The data were analyzed with SPSS. Some of the outstanding findings of the research are: Journalism formation is a conscious choise but dynamics that break this enthusiasm come into play during education and after graduaiton. Although graduates kept mentally envision such as "ideal journalism", "journalism as an honourable profession", they questioning the journalism in Turkey and see as a "dangerous profession". They prefer to do journalism abroad. Most of them with a professional orientation in journalism work in local organizations as reporter. However, they don't intend to do journalism for a long time for economic reasons. Graduates turn to non-journalistic professional fields because of economical reasons and negative conditions of journalism in Turkey. Most of them work as a "worker" in the private sector. Findings show that unemployment is a reality of journalism and a big issue after the graduation.
\end{abstract}

Keywords: Journalism education, journalism graduates, professional orientation, employement of journalists.

\section{Giriș}

Türkiye'de gazetecilik mezunlarının istihdam sorunu bilinen bir gerçektir. Politik ve ekonomik konjonktür, hükümetlerin medya üzerinde süregelen baskı politikaları, sektörün daralması gibi pek çok makro neden sorunu kronikleştirmekte ve her yıl daha çok sayıda mezun bu gerçekle yüz yüze gelmektedir.

Mezunların önemli çoğunluğu zorlayıcı koşullar nedeniyle (politik ve kurumsal baskılar, sansür, ifade özgürlüğü kısıtlamaları, güvencesiz çalışma, düşük ücret vb.) gazetecilik 
yap(a)mazken, bir tercih olarak da gazetecilik dışı mesleki alanlara ve iş sahalarına yönelebilmektedirler. Bu yönelimde, bilinen nedenlerin yanında bizzat gazetecilik eğitim sürecinin kendisi de mesleki algının şekillenmesinde rol oynayarak etkili olabilmektedir.

Bu makale ${ }^{2}$ yukarıda anlatılan çerçevede, gazetecilik mezunlarına ilişkin kişisel bir gözlemin bir sorunsala dönüştürülmesiyle ortaya çıkmıştır. Mezunların çoğunun gazetecilik dışı alanlarda ya da geçici işlerde çalıştığına yönelik olan bu gözlem, bir araştırma konusu olarak tasarlanmıştır. Gazetecilik mezunlarının işsizliğine ilişkin bilinen gerçekliğin ötesinde, hangi mesleki alanlara -tercihen ya da zorunlu olarak- eğilim gösterdikleri ve hangi alanlarda istihdam olduklarına ilişkin çalışma sayısı sınırlıdır. Araştırma, mezunların gazetecilik ya da gazetecilik dışı alanlara yönelim düzeylerini belirlemeye ve buna ilişkin bir profil çıkarmaya çalışmakta, bu profilin oluşmasında lisans eğitiminden gazeteciliğin makro problemlerine kadar etkili olabilen dinamikleri araştırmayı hedeflemektedir.

\section{Literatür}

\section{1. İstihdam Sorunu Bağlamında Türkiye’de Gazetecilik Eğitimi}

Gazetecilik eğitiminin üniversite düzeyinde verilmeye başlanması ve kurumsallaşması, sosyal bilimlerin gelişmesi, basın sektörünün ortaya çıkışı ve nitelikli işgücü talebi ve gazetecilik eğitimine yönelik talebin artışıyla (Yıldırım, 2012: s. 415) paralel olarak gerçekleşmiştir. Öncüller 1950'lerde eğitime başlayan basın-yayın yüksekokullarıdır. Fakülteye dönüşme süreci ise 1992 yılında mümkün olmuş ve ilk anda 7 yüksekokul (Ankara, Gazi, Ege, İstanbul, Marmara, Anadolu ve Selçuk) fakülte statüsüne geçmiştir. Bugünkü sistemde, "medyanın yapılanması ve akademik örgütlenmeler çerçevesinde bölümlere ayrılarak, devlet, vakıf ve Yüksek Öğretim Kurumu (YÖK) sınav sistemiyle öğrenci kabul eden diğer ülkelerin üniversitelerindeki iletişim fakültelerinde ve meslek yüksek okullarında devam etmektedir" (Yıldııım, 2012: s. 439-440).

Gazetecilik eğitiminin uygulama becerileri yüksek ve sektörün ihtiyacını karşılayacak gazeteciler mi yoksa toplumsal sorunların nasıl haberleştirilmesi gerektiğine dair entelektüel becerileri öne çıkan gazeteciler mi yetiştirmeye hizmet edeceği her zaman tartışma konusu olmuştur. Uygulamayı öne çıkaran anlayış "iş"in nasıl yapılacağını bilen gazeteci yetiştirmeye odaklanırken, kuram ağırıklı formasyon haber anlatılarının içeriğinin yani anlamın nasıl oluşturulacağına haiz, sosyal sorumluluk sahibi gazeteciler yetiştirmeye odaklanır. Akademi ve sektör arasındaki gerilimin de kaynağı olan bu tartışmalar bugün itibariyle gazetecilik eğitiminin endüstrideki dijital eğilimlere karşılık verip veremediğine ilişkin tartışmalarla yeni boyutlar kazanmıştır. İletişim eğitiminin gelişimini üniversitelerin piyasacı zihniyetle çalışmaya başlamasına ve sermaye çevrelerinin iletişime yönelik ilgisine bağlayan Dağdaş (2011: s. 38-39), eğitimin aslında daima sektöre hizmet ettiğini, "tarihsel olarak gazetecilik enstitülerinden iletişim fakültelerine giden süreçte, asıl amaç sektörün gereksinimlerini gözetmek ve taleplere yanıt vermeye çalışmak olmuştur" sözleriyle dile getirmektedir. 
Eğitim alanındaki faaliyetlerin bir standarda kavuşturulmasını amaçlayan akreditasyon çalışmalarının yakın zamanda iletişim fakülteleri için de gündeme gelmesi alanda bir hareketlenmeye yol açmıştır. İletişimi eğitimi akreditasyonu için yetkilendirilen ILEDAK (Illetişim Eğitimi Değerlendirme ve Akreditasyon Kurulu) araçlığıyla belirlenen kriterleri (fiziki koşullar, ders programı içeriği ve krediler vb) karşılayan fakülte, bölüm ya da programlar akredite olmuşlardır³. Eğitim programlarının akreditasyon kriterleri bağlamında ele alınmasının, iletişim eğitimindeki tartışma yaratan farklılaşmaları bir standarda bağlayarak düzenleyeceği öngörülmektedir.

\subsection{Gazetecilik Mezunlarında İșsizlik Gerçeği}

Eğitimle ilgili tartışmalar süredursun, Türkiye'de gazetecilik mezunlarının işsizlik sorunu kanıksanmış bir gerçekliğe dönüşmüştür. DiSK-AR'ın (2018), TÜiK'in açıkladığı Şubat 2018 Hane Halkı İşücü Araştırması'nı değerlendiren raporuna göre, Türkiye'de yüksek öğrenim işsizlik oranı yüzde 11.4'dir. İşsizlik oranının en yüksek olduğu alanlar ise mezun istatistiklerine göre, iş güvenliği $(\% 23,5)$, sosyal hizmet $(\% 24)$, sanat $(\%$ $21,2)$ ve gazeteciliktir $(19,2)$.

Tablo 1.'de (Narin, 2019), gazetecilik mezunlarının 2014, 2015 ve 2016 yıllarındaki işsizlik oranlarının dağılımı görülmektedir.

Tablo 1. Gazetecilik Mezunu İşsiz Sayısı ve İşsizlik Oranı

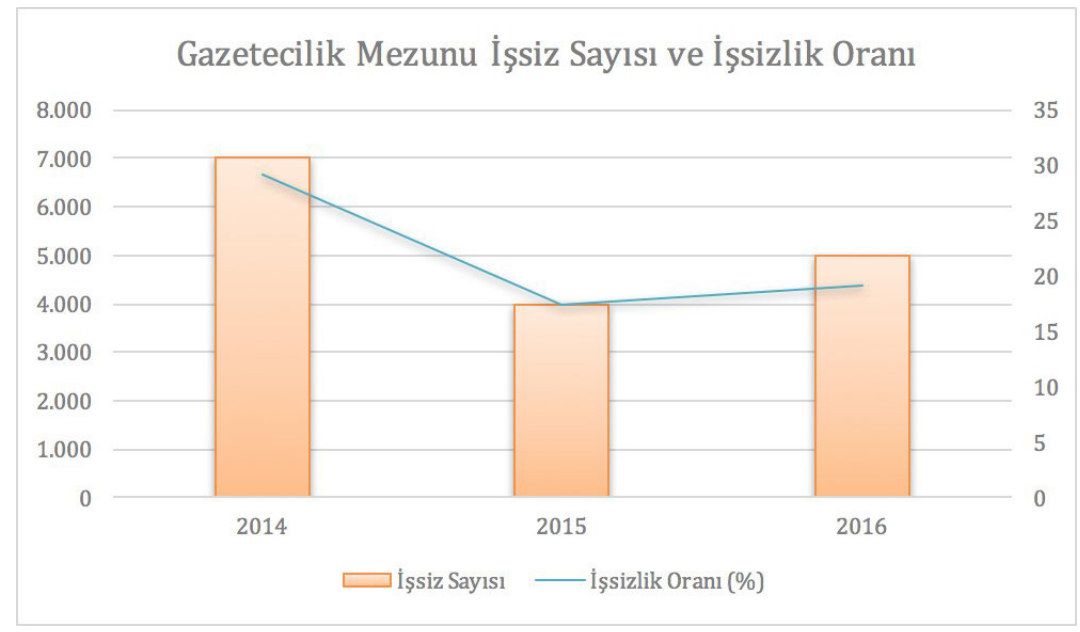

İşsizlik gerçeğine rağmen, iletişim fakülteleri ve verilen mezun sayısı her geçen yıl artmaktadır. YÖK Bilgi Sistemi (YÖKSiS) 2018 verilerine göre Türkiye'deki iletişim eğitimi veren kurumların, araştırmanın yapıldığı 2017 yılında verdiği toplam gazetecilik mezunu sayısı örgün öğretimde 918, ikinci öğretimde ise $434^{\prime}$ tür ${ }^{4}$. Medya sektörünün

3 Araştırmanın yazıldığı tarih itibariyle akredite olan kurumlar Bahçeşehir, Ankara, Uluslararası Kıbrıs, Yaşar, Aydın ve Sakarya üniversiteleridir.

4 Yükseköğretim Program Atlası'nda, lisans gazetecilik programı altında yer alan devlet ve vakıf üniversitelerinin, 26.11.2018 tarihli verileri mevcut olanların toplamı alınarak hesaplanmıştır. Kıbrıs ve Kırgızistan üniversiteleri dâhil edilmemiştir. (https://yokatlas.yok.gov.tr/lisans.php?y=104790033 adresinden 06.11.2019 tarihinde elde edilmiştir.) 
“iş güvencesi” açısından Türkiye'de en kötü durumdaki üç iş alanından biri olması dahi, iletişim fakültelerinin sayısal artışını engelleyememiştir (Dağdaş, 2011: s. 38). Bu artış eğitimin niteliğine, olanaklarına ve motivasyonuna doğrudan etki eden sorunları beraberinde getirmektedir. Kimi fakülteler öğretim kadrosu yetersizliği, kimileri öğrenci yokluğu, kimileri alt yapı yetersizlikleriyle mücadele ederken, eski ve büyük fakültelerde ise akademik kadrolarda yoğunlaşma, programların ve kadroların yenilenememesi, ödeneksizlik gibi sorunlarla boğuşulmaktadır.

Tüm açmazlarına rağmen gazetecilik mezunlarının işsizliğini sadece eğitimin niteliğine bağlayarak değerlendirmek dar bir perspektiftir. Mezunlar sektörün beklentilerini karşılayan bir eğitim almadıkları için değil, aslen medya piyasasının kendi iç yapısal sorunları, sektörün daralması, gazetecilik faaliyetlerinin politik ve ekonomik güç odakları tarafından sürdürülemez hale getirilişi, kurumların zayıflatılması, medya sermayesinin ve siyasi iktidarla ilişkilerin yandaş-muhalif geriliminde biçimlenmesi, dolayısıyla mesleğe yüklenen anlamın örselenmesi gibi sebeplerle de mesleği icra edememektedirler. Öyle ki gazetecilik yapmaktan erken evrelerde vazgeçebilmektedirler. Bu vazgeçiş eğitimin yeterli vasıfları kazandır(a)mamasının ötesinde, mesleğe yönelimdeki gönülsüzlükle ilgilidir.

\subsection{0'li Yıllarda Türkiye’de Gazetecilik Faaliyetinin Koșulları}

Çalışmanın 2010 yılı ve sonrası gazetecilik mezunlarını kapsaması ve bu grupta lisans başlangıcının en erken 2005/2006 yılı olabileceği varsayılırsa, 2000'lerin başından itibaren Türkiye'de gazeteciliğin genel görünümüne ilişkin bir kaç söz söylemek bir bağlam oluşturmak açısından yararlı olacaktır.

Türkiye'de siyasi ve ekonomik bir dönüm noktası olarak yaşanan 2001 ekonomik krizi, medya sahiplik yapısında ciddi bir dönüşümün başlangıcıdır. Krizde batan bankaları nedeniyle birçok medya sahibi sektörden çekilirken, Tasarruf Mevduatı Sigorta Fonu'nun (TMSF) el koyduğu medya kuruluşları 2002'de iktidara gelen AKP'nin inisiyatifinde hükümete yakın sermaye sahiplerine devredilmeye başlanmış ve planlı bir süreçte çoğu hükümetin kontrolüne geçmiştir. Basın sektöründe istihdam sorunun devasa boyutlara ulaştığı 2001 krizini müteakip, "medya patronlarının 'fırsat bu fırsat' zihniyeti ile gazeteciler üzerinde kıyım gerçekleştirerek sendikanın olmadığı, Basın İş Yasası'nın işletilmediği" (Uçak, 2011: s. 391) bir sürece girilmiştir. Çalışma ve Sosyal Güvenlik Bakanlığı'nın verilerine göre, 2003 yılında Türkiye'de basın yayın kuruluşlarında işten çıkarılanların sayısı 6078'dir (Uçak, 2011: s. 391).

1980 'lerden beri süregelen örgütlülük sorunu 2001 'de işten çıkarılanları savunacak kolektif bir yapının bulunmaması şeklinde tezahür etmiştir. Bu şartlar altında medya sektörü ve özel olarak da gazetecilik, sendikal örgütlenmenin engellendiği, düzensiz ve ağır çalışma koşullarının, işsizliğin, eksik istihdamın emek sömürüsünün, adaletsiz ücret uygulamalarının olduğu bir çalışma alanı haline gelmiş ve sektördeki çalışma ilişkilerine ait bu olumsuz pratikler çoktan meşruiyet kazanmıştır (Seçkin, 2010: s. 62). Tokgöz'e (2003) göre, sendikasızlaşma nedeniyle kriz derinleşip işsiz sayısı artarken, medya sektöründeki küçülme hem medya çalışanları hem de iletişim fakültelerinden yeni mezun olanların aleyhine işlemiştir. 
Literatür incelendiğinde özetlenen bağlamda, Türkiye medyasının geçmişteki ve hâlihazırdaki sorunlarını ele alan birçok araştırma mevcuttur. Genelde iletişim, özel olarak da gazetecilik eğitimini ve sorunlarını konu edinen çalışmalara (Özbek, 1992; Tokgöz, 2003 ve 2006; Gezgin, 2005; Uzun, 2007 ve 2011; Dağtaş, 2011; Öztürk, 2011; Şeker ve Şeker, 2011; Ergeç, 2014; Yıldırım, 2006 ve 2016; Ezber ve Sayar, 2016; Büyükbakkal ve Büyükbakkal, 2018; Dirik ve Çambay, 2019) sıkça rastlanmaktadır. Bazı araştırmalar (Büyükaslan ve Mavnacıoğlu, 2017; Narin, 2018; Karaduman ve Akbulutgiller, 2017; Güz vd. 2017; Akgül vd., 2018) eğitim programı içeriklerine odaklanmaktadır. Yanı sıra karşılaştırmalı çalışmalar (Kandemir, 2012; Yıldırım, 2012; Karaarslan, 2019), iletişim akademisyenlerini konu edinen çalışmalar (Bayram ve Arık, 2011; Temel ve Önürmen, 2017; Akgül ve Akdağ, 2018); öğrenci, akademisyen ve meslek mensuplarını birlikte ele alan çalışmalar (Atabek ve Şendur Atabek, 2014) ve çalışan gazetecilerin sorunlarına odaklanan çalışmalar (Altun, 1995; Öke, 1994; Seçkin, 2010; Ş. Öztürk, 2017) bu konuda zengin bir literatüre işaret etmektedir. Süreci ekonomi-politik açıdan değerlendiren ve sorunları çok boyutlu tartışan araştırmalar ise (Sözeri, 2014; Sönmez, 2014; Mavioğlu, 2014; Çam ve Yüksel, 2015; Aydın, 2015; Adaklı, 2010) bağlamsal bir çerçeve sunmaktadır.

Literatürde doğrudan gazetecilik mezunlarına ilişkin çalışmaların ise sınırlı (Atabek vd., 2000) olduğu dikkati çekmektedir. Gazetecilik eğitimi ve mesleğe bakışla ilgili bu çalışmaya benzer bir araştırmanın Korkmaz (2012) tarafından yapıldığı görülmektedir. Daha ziyade istihdam raporları ve istatistiklere konu olan mezunlara yönelik araştırmalarınsa, eğitimin niteliği, beklentiler ve gereksinim duyulan dönüşümler kadar, alana çıkanların deneyimlerini resmetmek açısından da aydınlatıcı ve yol gösterici olacağı düşünülmektedir. Bu çerçevede bu çalışmanın literatüre, ele alınan örneklem düzeyinde betimsel bir katkı sağlayacağı ve daha sonra yapılacak uyarlamalar veya genişletilmiş ölçekli çalışmaları destekleyeceği öngörülmektedir.

\section{Yöntem}

\subsection{Araștırmanın Amacı}

Araştırmanın öncelikli amacı, gazetecilik mezunlarının işsizliği ve mesleki yönelimlerine ilişkin gündelik gözlemlere dayanan önermeleri, araştırma soruları aşağıda ayrıntılı olarak ifade edilen bir araştırmayla sınamaktır. Bu niyetle, sınırlı bir örnekleme uygulamak üzere temel düzeyde, betimleyici ampirik bir araştırma tasarlanmıştır. Yöntem olarak, araştırma sorularını nicel veriler ve tutum ölçümleriyle cevaplamaya yönelik bir soru formunun kullanıldığı alan araştırması uygulanmıştır.

Araştırma soruları, 3 katılımcı profiline (gazetecilik eğitimi alanlar, gazetecilik alanında çalışanlar, gazetecilik dışı alanlarda çalışanlar) yönelik olarak sınıflandırılmıştır:

Gazetecilik eğitimi alanlar,

- Gazeteciliği hangi nedenlerle ve hangi sırada tercih etmektedir?

- Gazetecilik eğitimi, mesleğe ve sektöre ilişkin görüşleri nelerdir?

- Mezuniyet sonrası yönelimleri, gazetecilik veya gazetecilik dışı hangi mesleki alanlarda ve pozisyonlarda dağılım göstermektedir? 
- Mesleki yönelimlerinde hangi dinamikler etkili olmaktadır?

- Gazetecilik alanında çalışanlar,

- Gazetecilik mesleğini yapanlar hangi alanlarda ve pozisyonlarda çalışmaktadırlar?

- Mesleği sürdürme eğilimlerinin yönü nedir?

- Meslekte iş değiştirme sıklıkları ve nedenleri nelerdir?

- Mesleki pratiğe ilişkin değerlendirmeleri (politik görüşlerini çekinmeden açıklayabilme, inisiyatif kullanabilme, güvencede hissetme) ne yöndedir?

- Gazetecilik dışı alanlarda çalışanlar,

- Hangi mesleki alanlarda ve statülerde dağılım göstermektedirler?

- İşsizlik oranı nedir?

- Öğrencilik ve mezuniyet sonrası gazetecilik deneyimleri nedir?

- Gazetecilik yapmama kararlarında etkili olan dinamikler nelerdir?

- Gazeteciliği meslek olarak seçmemelerindeki sebepler nelerdir?

- Mevcut mesleki tercihlerinin nedenleri nelerdir?

\subsection{Evren ve Örneklem}

Araştırmada Ege Üniversitesi İletişim Fakültesi Gazetecilik Bölümü mezunları çalışma evreni kabul edilerek, 2010-2017 yılları arası mezun olan öğrenciler örneklem çerçevesi (erişilebilir nüfus) olarak belirlenmiştir. 2010-2017 yılları arasında verilen mezun sayısı, E.Ü. İletişim Fakültesi öğrenci işleri bürosundan edinilen kayıtlara göre örgün ve ikinci öğretimde toplam 835'tir. Çalışma, olasılıklı basit rastlantısal örnekleme yoluyla, ankete katılan 383 cevaplayıcı ile gerçekleştirilmiştir. 5 form geçersiz sayılarak 378 form araştırmaya dâhil edilmiştir. Örneklem büyüklüğü hesaplama tablosuna ${ }^{5}$ göre gerekli örneklem büyüklüğüne ulaşılmıştır.

\begin{tabular}{|l|c|}
\hline Güven düzeyi & $\% 99$ \\
\hline Güven aralığı & 0,05 \\
\hline Gerekli örnek büyüklüğü & 371 \\
\hline 378 örneklem büyüklüğü için hata payı & 3.73 \\
\hline
\end{tabular}

Veri toplama aracı olarak anket tekniği kullanılmıştır. Araştırmaya katılanlara demografik, çoktan seçmeli ve likert tipi değerlendirme sorularından oluşan 26 maddelik bir soru formu uygulanmıştır. Katılımcılar, gazetecilik alanı veya gazetecilik dışı bir alanda çalışma durumuna bağlı olarak 13. sorudan itibaren farklı sorulara yönlendirilmişlerdir.

Veri toplama sürecinde örnekleme online yöntemlerle (sosyal medya hesapları ve eposta) erişim sağlanmıştır. Soru formu, hedef örnekleme çevrim içi ortamda birebir ulaştırılmıştır. Veriler, 2017'nin son 6 ayı ile 2018'in ilk 2 ayında derlenmiştir. Elde edilen veriler, örnekleme ilişkin betimleyici bir profil çıkarma amacına yönelik olarak SPSS'te betimsel istatistik analizlere (frekans analizi) tabi tutulmuştur. Bulguları değerlendirmek için merkezi eğilim hesaplamalarına başvurulmuştur. Bir dağılımın merkezi eğilimi, değerlerin dağılımının 'merkezinin' ölçümüdür (Geray, 2014: s. 87). Merkezi eğilim üç 
farklı ölçümle elde edilebilir: ortalama (mean), ortanca (median) ve tepedeğer (mode). $\mathrm{Bu}$ araştırmanın bulguları, merkezi eğilimi yansıtan tepe değer (mode) ve ortalama (mean) ölçümleri baz alınarak yorumlanmıştır. Tutum ölçmeye yönelik önermelerin yer aldığı tablolarda (Tablo 5., Tablo 6. ve Tablo 13. frekans (f) dağılımı ve merkezi eğilim ortalamalarına yer verilmiştir. Diğer tablolarda ise frekans ve yüzdelik dağılımlar üzerinden değerlendirme yapılmıştır. Ayrıca, gerekli görülen bazı soru ve önermelerde, demografik faktörler bakımından farklılaşmaları ortaya koyabilmek için SPSS’te çapraz tablo (cross-tabulation) analizleri yapılmış ve elde edilen bulgulara ilişkin değerler metin içinde verilerek yorumlanmıştır.

\subsection{Araștırmanın Sınırlılıkları}

Araştırmanın sınırlılıklarından biri, anketin çevrimiçi ortamda uygulanmasıdır. Sosyal medya hesabı olmayan ya da öğrenci bilgi sistemine kayıtı e-posta hesaplarını kullanmayan örnekleme erişimde güçlük çekilmiş, bu durum örneklem sayısının muhtemel artışını sınırlamıştır. Araştırmanın 2010-2016 yılları mezunlarına ait verileri 2017 yılının son 6 aylık döneminde derlenmiş, 2017 yılı mezunlarının verilerine ise mezuniyeti takip eden yaz döneminin geçmesini müteakip 2018 yılının ilk ayında ulaşılmıştır. Saha araştırmasının uygulandığı tarihten araştırmanın raporlanma ve yayınlanmasına kadar geçen zaman düşünüldüğünde, bazı bulguların (örneğin gelir düzeyi) araştırmanın uygulandığı dönemi bağladığı hatırlatılmalıdır. Araştırma uygulandıktan sonra iş bulanlar, iş değiştirenler, gazetecilik alanında çalışmaya başlayanlar ya da gazetecilikten farklı meslek kollarına geçenler söz konusu olabilir ve ancak araştırmanın güncellenmesi durumunda yeni bulgular ortaya çıkabilir.

Bir diğer sınırlılık uygulanan analizlerle ilgilidir. Çalışma, temel düzeyde betimsel bir araştırma olarak tasarlanmış ve ana problemi mezunların mesleki yönelimine ilişkin genel bir profil çıkarılması olarak belirlenmiştir. Bu amaca yönelik olarak araştırma soruları belirlenmiş ve bu sorulara betimleyici istatistiki analizlerle (frekans analizi) yanıt aranmıştır. Farklı analizlerle veriler arasındaki ilişki ve farklılaşmaları ortaya koymak mümkün olmakla birlikte, araştırmanın betimsel düzeyde tasarlanması nedeniyle yorumlama planlanan sınırlar çerçevesinde gerçekleştirilmiştir.

\section{Bulgular}

Araştırma bulguları, 4 kategoride değerlendirilmiştir.

\subsection{Demografik Bulgular}

\subsection{Mezunların Gazetecilik Eğitimi, Mesleğe ve Sektöre Yaklaşımına IIlişkin Bulgular}

\subsection{Mesleki Yönelimi Gazetecilik Alanında Olan Katılımcılara Illişkin Bulgular}

\subsection{Mesleki Yönelimi Gazetecilik Dışı Alanlarda Olan Katıımcılara İlişkin Bulgular}

Örneklemin mezuniyet yılına, öğretim türüne göre dağılımları ve araştırmaya katıım oranları şöyledir: 
Tablo 1. Mezuniyet Yılı ve Öğretim Türü Bazında Araştırmaya Katılım Oranları

\begin{tabular}{|l|c|c|c|c|c|c|}
\hline \multirow{2}{*}{ Mezuniyet Yılı } & \multicolumn{4}{|c|}{ Mevcut } & \multicolumn{3}{c|}{ Araştırmaya Katılan } \\
\cline { 2 - 7 } & Örgün & i.Ö. & Toplam & Örgün & i.Ö. & Toplam \\
\hline $2009-2010$ & 78 & - & 78 & 21 & - & 21 \\
\hline $2010-2011$ & 74 & - & 74 & 23 & - & 23 \\
\hline $2011-2012$ & 72 & - & 72 & 28 & - & 28 \\
\hline $2012-2013$ & 82 & - & 82 & 21 & - & 21 \\
\hline $2013-2014$ & 70 & - & 70 & 37 & - & 37 \\
\hline $2014-2015$ & 72 & 42 & 114 & 37 & 28 & 65 \\
\hline $2015-2016$ & 98 & 62 & 160 & 67 & 44 & 111 \\
\hline $2016-2017$ & 91 & 94 & 185 & 32 & 40 & 72 \\
\hline Toplam & 637 & 198 & 835 & 266 & 112 & 378 \\
\hline
\end{tabular}

Tablo 1.'de görüleceği gibi, araştırmaya en yüksek katılımı, 67 örgün ve 44 ikinci öğretim mezunu olmak üzere toplam 111 kişi ile 2016 yılı mezunları göstermiştir. Önceki yıllara doğru gidildikçe katıım oranındaki düşüklük erişim güçlüğüyle açıklanabilir. Genel katılım düzeyine bakıldığında, örneklemin \% 70,4’ü (266) örgün öğretim; \% 29,6'sı (112) ise ikinci öğretim mezunudur.

\subsection{Demografik Bulgular}

Örnekleme ilişkin demografik bulgular Tablo 2.'de gösterilmiştir.

Tablo 2. Katılımcıların Demografik Profili

\begin{tabular}{|c|c|c|c|c|c|}
\hline Cinsiyet & $f$ & $\%$ & Yaşadığı yer & $f$ & $\%$ \\
\hline Kadın & 175 & 46,3 & Yurt dışı & 13 & 3,4 \\
\hline Erkek & 200 & 52,9 & Büyük şehir & 344 & 91 \\
\hline Diğer & 3 & 0,8 & Taşra & 13 & 3,4 \\
\hline Toplam & 378 & 100 & Türkiye & 8 & 2,1 \\
\hline Medeni durum & $f$ & $\%$ & Toplam & 378 & 100 \\
\hline Evli & 54 & 14,3 & Aylık bireysel ort. gelir & $f$ & $\%$ \\
\hline Bekar & 318 & 84,1 & 750 tl'den az & 79 & 20,9 \\
\hline Diğer & 6 & 1,6 & $750-1.400 \mathrm{tl}$ arası & 103 & 27,2 \\
\hline Toplam & 378 & 100 & $1.401-2.400 \mathrm{tl}$ arası & 133 & 35,2 \\
\hline Yaş grupları & $f$ & $\%$ & $2.401-4.000 \mathrm{tl}$ arası & 40 & 10,6 \\
\hline $21-25$ & 163 & 43,1 & $4.001-7.000 \mathrm{tl}$ arası & 16 & 4,2 \\
\hline $26-30$ & 167 & 44,2 & 7.000 tl üzeri & 7 & 1,9 \\
\hline $31-35$ & 39 & 10,3 & Toplam & 378 & 100 \\
\hline 36 ve üzeri & 9 & 2,4 & & & \\
\hline Toplam & 378 & 100 & & & \\
\hline
\end{tabular}




\begin{tabular}{|l|c|c|}
\hline Politik görüşleri & $\mathbf{f}$ & $\%$ \\
\hline Muhafazakâr & 4 & 1,1 \\
\hline Muhafazakâr/Milliyetçi & 13 & 3,4 \\
\hline Milliyetçi & 17 & 4,5 \\
\hline Liberal/Demokrat/Sosyal Demok. & 56 & 14,8 \\
\hline Atatürkçü/Kemalist/Cumhuriyetçi & 118 & 31,2 \\
\hline Sosyalist/Komünist/Devrimci & 70 & 18,5 \\
\hline Anarşist & 7 & 1,9 \\
\hline Belirtmek istemiyorum & 73 & 19,3 \\
\hline Diğer & $\mathbf{2 0}$ & 5,3 \\
\hline Toplam & $\mathbf{3 7 8}$ & $\mathbf{1 0 0}$ \\
\hline
\end{tabular}

Tablo 2.'deki demografik bulgular özetlendiğinde;

Cinsiyet: \% 52,9 (200) erkek, yüzde 46,3 (175) kadın, yüzde 0,8 (3) diğer şeklindedir.

Yaş grubu: \% 43,1 (163) 21-25 yaş; \% 44,2 (167) 26-30 yaş; \% 10,3 (39) 31-35 yaş ve \% 2,4 (9) 36 ve üzeri yaş şeklinde dağılmaktadır.

Medeni durum: \% 84,1 (318) bekar, \% 14,3 (54) evlidir. Bu soruya \% 1,6 (6) katılımcı diğer yanıtını vermiştir.

Yaşadığı yer: Araştırmaya katılanların \% 91,6’sı (347) Türkiye nüfusuna göre büyük şehir statüsündeki illerde (İzmir, İstanbul, Ankara, Bursa, Antalya, Eskişehir, Malatya, Mardin, Balıkesir, Manisa, Aydın, Muğla ve Denizli) yaşamaktadır. Yurt dışında (Almanya, İsviçre, İtalya, Fransa, Kıbrıs) yaşayanlar örneklemin \% 3,4'ünü (13) oluştururken, \% 3,4'lük (13) örneklem ise taşra illerde yaşamaktadır. Bu soruya Türkiye yanıtını veren \% 1,6 (6) katılımcı yaşadığı yer konusunda ayrıntı vermekten kaçınmıştır.

Aylık bireysel ortalama gelir düzeyi: 2017 yılı baz alındığında aylık bireysel ortalama gelir düzeyi bakımından örneklemin \% 20,9'u (79) 750 tl'den az gelir diliminde yer almaktadır. \% 27,2'si (103) 750-1400 tl arası; \% 34,7'si (133) ise 1401-2.450 tl arası gelir düzeyine sahiptir. Örneklemin \% 10,6'sı (40) 2.401-4000 tl arası; \% 4,2'si (16) 4001-7000 tl arası; \% 1,9'u (7) ise 7000 tl ve üzeri gelir elde etmektedir. Buna göre, örneklemin yaklaşık \% 90'dan fazlası yoksulluk sınırı ve/veya daha altı gelir düzeyindedir. \% 48'e yakını ise asgari ücret ve altında gelir elde etmektedir.

Politik görüşleri: Örneklemin \% 30,8'i kendisini Atatürkçü/Kemalist/Cumhuriyetçi olarak tanımlamıştır. \% 19,3’ü (73) politik görüşünü belirtmek istemediğini bildirmiştir ve bu nedenle gizleme eğilimi nispeten yüksek bir oran olarak belirmiştir. \% 18,5 (70) kendisini sosyalist/komünist/devrimciolarak tanımlarken, \% 14,8 (56) liberal/demokrat/ sosyal demokrat; \% 4,5 (17) katılımc milliyetçi; \% 1,9 (7) anarşist; \% 3,4 (13) milliyetçi/muhafazakâr; \% 1,1'i (4) de muhafazakâr politik görüşlere sahip olduğunu ifade etmiştir. Diğer seçeneğini işaretleyen \% 5,3 (20) ise politik görüşlerini feminist, apoli- 
tik, Türkçü, cumhuriyetçi/liberal, muhalif, özgürlükçü, hümanist ya da hiçbiri şeklinde tanımlamıştır.

\subsection{Mezunların Gazetecilik Eğitimi, Mesleğe ve Sektöre Yaklașımına İlișkin Bulgular}

Bu kategoride örneklemin üniversite tercih sıralamasında gazetecilik bölümünün yeri, gazeteciliği tercih etme nedenleri ve gazetecilik eğitimine yaklaşımlarına ilişkin bulgular yer almaktadır.

Gazetecilik Bölümü tercih sırası: Tablo 3.’te araştırmaya katılanların üniversite tercih sıralamalarında gazetecilik bölümünün yeri görülmektedir.

Tablo 3. Gazetecilik Bölümü Tercih Sıralamalarının Dağılımı

\begin{tabular}{|l|c|c|}
\hline Gazetecilik bölümü kaçıncı tercihinizdi? & $\mathbf{f}$ & $\%$ \\
\hline İlk tercihimdi & 147 & 38,9 \\
\hline İlk üç tercihimden biriydi & 135 & 35,7 \\
\hline Illk üçten sonraki tercihimdi & 78 & 20,6 \\
\hline Hatırlamıyorum & 18 & 4,8 \\
\hline Toplam & $\mathbf{3 7 8}$ & $\mathbf{1 0 0}$ \\
\hline
\end{tabular}

Tablo 3.'e göre, örneklemin \% 38,9'unda (147) gazetecilik bölümünün ilk tercih olduğu görülmektedir. \% 37,7'sinin (135) ise ilk üç tercihinden biridir. Bu bulgulara göre gazetecilik lisans eğitiminin, örneklemin dikkate değer bir çoğunluğunda bilinçli ve iradi bir tercih olduğu anlaşılmaktadır.

Gazetecilik bölümünü tercih etme nedenleri: Araştırmaya katılanlara gazetecilik bölümünü tercih nedenleri sorulmuş ve en fazla 3 seçenek işaretleyebilecekleri belirtilmiştir. Seçenekler üzerinde toplam 651 işaretleme yapılmıştır. Dağılım Tablo 4.'te görülmektedir.

Tablo 4. Gazetecilik Bölümünü Tercih Etme Nedenleri

\begin{tabular}{|l|c|c|}
\hline $\begin{array}{l}\text { Gazetecilik bölümünü tercih etme nedeniniz neydi? } \\
\text { (En çok 3 seçenek) }\end{array}$ & $\mathbf{f}$ & $\%$ \\
\hline Kişisel merak/ilgi ve heves & 274 & 71,7 \\
\hline Karakterime uygun olması & 149 & 39 \\
\hline Örnek aldığım popüler/tanıdık bir gazeteci & 24 & 6,3 \\
\hline Ailede örnek aldığım bir gazeteci & 15 & 3,9 \\
\hline Öğretmen/arkadaş/aile tavsiyesi & 25 & 6,5 \\
\hline Sosyal ve siyasal prestij sağlaması & 31 & 8,1 \\
\hline Olaylara tanıklık etmek & 80 & 20,9 \\
\hline Çevre edinmek & 4 & 1 \\
\hline Tamamen tesadüf & 34 & 8,9 \\
\hline
\end{tabular}




\begin{tabular}{|l|c|c|}
\hline Diğer & 15 & 3,9 \\
\hline
\end{tabular}

Gazetecilik bölümünün tercih edilmesinde merkezi eğilim, tepe değer (274 frekans) bulgularına göre \% 71,7 oranıyla kişisel merak/ilgi ve heves olarak öne çıkmıştır. İkinci sırada, \% 39 (149) oranıyla karakterime uygun olması seçeneği yer alırken, olaylara tanıklık etmek \% 20,9 (80) oranıyla en çok işaretlenen üçüncü seçenek olmuştur. Bulgular, geleneksel anlamda gazetecilik mesleğinin gerekliliklerini karakterize eden motivasyonların tercihlere yansıdığını düşündürmektedir. Seçeneklere yapılan işaretlemelerin frekans dağılımında kadın ve erkekler açısından belirgin bir fark izlenmemekle birlikte, çapraz tablo analizi bulgularına göre cinsiyetler arası dikkat çeken fark sosyal ve siyasal prestij sağlaması (10 kadın, 21 erkek), çevre edinmek (kadın 0 , 4 erkek) seçeneklerinde ortaya çıkmaktadır. Buna göre, erkek katılımcıların tercihinde gazeteciliğin sosyal ağ ve prestij sağlama fonksiyonları daha motive edici faktörlerdir. Yine örnek aldığım popüler/tanıdık bir gazeteci seçeneği erkeklerde 15, kadınlarda 8 frekansa sahiptir. Gazetecilik mesleğindeki rol modellerin erkek katılımcıların tercihinde daha belirleyici olduğu anlaşılmaktadır.

Gazetecilik eğitimine ilişkin görüşler: Bu çerçevedeki verilere ulaşmak için, araştırmaya katılanlara gazetecilik eğitimine ilişkin çeşitli önermelere yaklaşım düzeyi sorulmuştur. Tablo 5.'te görülen bulgular, katılımcıların genel olarak gazetecilik eğitimine ilişkin görüşleri, eğitim içeriğine (dersler) ilişkin görüşleri ve eğitim-sektör ilişkisine ilişkin görüşleri şeklinde 3 ayrı planda yorumlanmıştır.

Tablo 5. Gazetecilik Eğitimine Illişkin Görüşler

Kesinlikle katılıyorum:1 Katılıyorum:2 Fikrim Yok:3 Katılmıyorum:4 Kesinlikle Katılmıyorum:5

\begin{tabular}{|c|c|c|c|c|c|c|c|}
\hline \multirow{2}{*}{$\begin{array}{l}\text { Aldığınız gazetecilik eğitimini } \\
\text { düš̈ündügünüzde, aşağıdaki } \\
\text { görüşlere hangi düzeyde } \\
\text { katıırsınız? }\end{array}$} & \multicolumn{5}{|c|}{ (f) } & \multirow[b]{2}{*}{ (Mode) } & \multirow[b]{2}{*}{ (Mean) } \\
\hline & 1 & 2 & 3 & 4 & 5 & & \\
\hline $\begin{array}{l}\text { Gazeteci olmak için gazeteci- } \\
\text { lik eğitimi şarttır }\end{array}$ & 123 & 129 & 8 & 77 & 41 & 2 & 2,43 \\
\hline $\begin{array}{l}\text { Gazetecilik eğitimi mesleğe } \\
\text { katılımı teşvik etmektedir }\end{array}$ & 62 & 140 & 25 & 109 & 42 & 2 & 2,81 \\
\hline $\begin{array}{l}\text { Kurum dışı staj, mesleğe } \\
\text { katılımı teşvik etmektedir }\end{array}$ & 99 & 185 & 29 & 43 & 22 & 2 & 2,22 \\
\hline $\begin{array}{l}\text { Gazetecilik eğitimi için } 4 \text { yıl } \\
\text { uzun bir süredir }\end{array}$ & 74 & 90 & 18 & 129 & 67 & 4 & 3,07 \\
\hline $\begin{array}{l}\text { Gazetecilik eğitiminde kuram- } \\
\text { sal dersler gereklidir }\end{array}$ & 159 & 151 & 14 & 40 & 14 & 1 & 1,94 \\
\hline $\begin{array}{l}\text { Gazetecilik eğitiminde pratik } \\
\text { dersler yeterli düzeydedir }\end{array}$ & 16 & 53 & 19 & 132 & 158 & 5 & 3,96 \\
\hline $\begin{array}{l}\text { Gazetecilik eğitiminde teknik } \\
\text { olanaklar yeterlidir }\end{array}$ & 9 & 56 & 24 & 131 & 158 & 5 & 3,99 \\
\hline $\begin{array}{l}\text { Gazetecilik eğitiminde } \\
\text { mesleğe ilişkin dersler yet- } \\
\text { erlidir }\end{array}$ & 16 & 92 & 27 & 144 & 99 & 4 & 3,58 \\
\hline
\end{tabular}




\begin{tabular}{|l|c|c|c|c|c|c|c|}
\hline $\begin{array}{l}\text { Gazetecilik diploması, sadece } \\
\text { "üniversite mezunu" etiketine } \\
\text { sahip olmayı sağlar }\end{array}$ & 121 & 115 & 31 & 81 & 30 & 1 & 2,43 \\
\hline $\begin{array}{l}\text { Gazetecilik eğitimi sektörün } \\
\text { taleplerini karşılamaktadır }\end{array}$ & 18 & 69 & 46 & 134 & 111 & 4 & 3,66 \\
\hline $\begin{array}{l}\text { Gazetecilik alanındaki } \\
\text { eğitimcilerin sektörel tecrüb- } \\
\text { eye sahip olması şartır }\end{array}$ & 201 & 116 & 24 & 34 & 3 & 1 & 1,74 \\
\hline $\begin{array}{l}\text { Gazetecilik eğitimi sırasında } \\
\text { sektörde çalışmak, sonrası } \\
\text { için önemli bir avantajdır }\end{array}$ & 250 & 101 & 9 & 11 & 7 & 1 & 1,48 \\
\hline $\begin{array}{l}\text { Çocuğumun gazetecilik } \\
\text { eğitimi almasını isterim }\end{array}$ & 31 & 69 & 91 & 63 & 124 & 5 & 3,48 \\
\hline $\begin{array}{l}\text { Gazetecilik alanında eğitim } \\
\text { veren bir akademisyen olmak } \\
\text { isterim }\end{array}$ & 165 & 122 & 39 & 30 & 22 & 1 & 2,00 \\
\hline
\end{tabular}

Gazeteci olmak için gazetecilik eğitimi şarttır önermesinin tepe değeri (2) 129 frekansa sahiptir. Merkezi eğilim ortalama değeri 2,43’tür. Buna göre örneklemin merkezi eğilimi, gazeteci olmak için gazetecilik eğitiminin şart olduğu yönünde bir ağırlığa sahiptir.

Gazetecilik eğitimi mesleğe katılımı teşvik etmektedir önermesinde tepe değer (2) 140 frekanstır. Merkezi eğilim ortalaması ise 2,81'dir. Bu önermeye katılmayanların oranı da nispeten yüksektir ve kararsızlık eğilimi bir önceki önermeye oranla daha belirgindir. Merkezi eğilim ortalama değeri baz alındığında, gazetecilik eğitiminin mesleğe katılım açısından motive edici olduğu yönünde çok büyük olmasa da bir ağırlık söz konusudur.

Gazetecilik eğitimi için 4 yıl uzun bir süredir önermesinin tepe değeri (4) 129 frekanstır. Merkezi eğilim ortalama değeri 3,07'dir. Gazetecilik eğitimi için 4 yıllık süreyi uzun bulanlarla, makul bulanların toplam frekansları birbirine yakındır. Merkezi eğilim ortalamasına göre ise kararsızlık (fikrim yok) eğilimi belirgindir.

Gazetecilik diploması, sadece 'üniversite mezunu' etiketine sahip olmayı sağlar önermesinin tepe değeri (1) 121 frekans, merkezi eğilim ortalama değeri ise 2,43'tür. Bulgulara göre bu önermeye katılmayanlar da olmakla birlikte örneklemin merkezi eğilimi gazetecilik diplomasının sadece 'üniversite mezunu' etiketi anlamı taşıdığı fikrine daha yakındır. Türkiye'de gazetecilik eğitimi sonrası mezunları bekleyen işsizlik sorunu ve ilintili koşullar, gazetecilik diplomasının öğrenci nezdinde değersizleştirildiği izlenimini yaratan söylemlerde kendini gösterebilmektedir. Bulgular bu yorumu desteklemektedir.

Örnekleme sunulan, gazetecilik alanında akademisyen olmak isterdim önermesinin tepe değeri (1) 165 frekanstır. Merkezi eğilim ortalama değeri ise 2,00 olarak hesaplanmıştır. Örneklemin bu önermeye ilişkin merkezi eğilimi, gazetecilik alanında eğitim veren bir akademisyen olmak yönünde bir ağırlığa sahiptir. İşsizlik, askerlik, büyük şehirde kalma isteği gibi gerekçeler öğrencilerin lisansüstü eğitime yönelimini arttırabilmektedir. Bu bakımdan piyasada gazetecilik yapmaktansa, akademisyenliğin güvenceli ve uzun vadeli bir iş imkânı olarak görüldüğü söylenebilir.

Örnekleme yöneltilen önermelerden biri de, çocuğumun gazetecilik eğitimi almasını 
isterdim şeklindedir. Bu önermeye ilişkin tepe değer (5) 124 frekans, merkezi eğilim ortalama değeri 3,48'dir. Buna göre örneklemin önemli bir çoğunluğu, çocuğunun gazetecilik eğitimi alması fikrine mesafelidir.

Mezunların gazetecilik eğitiminin içeriğine ilişkin görüşleriyle ilgili bulgular ise şöyle özetlenebilir:

Gazetecilik eğitiminde kuramsal dersler gereklidir önermesinin tepe değeri (1) 159 frekanstır. Örneklemin merkezi eğilim ortalama değeri 1,94 olarak hesaplanmıştır. Dolayısıyla bu önermeye ilişkin merkezi eğilim yüksek oranda kuramsal derslerin gerekli olduğu yönündedir. Eğitim sürecinde öğrencilerin kuramsal derslerdense mesleğe yönelik uygulama derslerinin ağırıkta olması gerektiğine ilişkin talep ve şikâyetlerine tanıklık edilebilmektedir. Ancak bulgulara göre, eğitim sürecinde gözlenen kuramsal derslere ilişkin yaklaşımın istatistikî açıdan bir karşılığı olmadığı anlaşılmaktadır.

Gazetecilik eğitiminde pratik dersler yeterli düzeydedir önermesinde tepe değer (5) 158 frekanstır. Örneklemin merkezi eğilim ortalaması ise 3,94 olarak hesaplanmıştır. Yani örneklemin büyük bir bölümü mesleki pratiğe yönelik derslerin yeterli olmadığı görüşündedir. Bu bulguyu, öğrencilerin kuramsal dersler yerine uygulamalı dersleri tercih ettikleri şeklinde yorumlamak yanıltıcı olabilir. Bir önceki önermeyle uyuşmuyor gibi görünse de bu bulgunun, kuramsal derslerin yanı sıra pratik derslerin de bir ağırık kazanması yönünde bir beklentiye işaret ettiği söylenebilir.

Araştırmaya katılanlara, gazetecilik eğitiminde teknik olanaklar yeterlidir önermesi sunularak, eğitim sürecinde öğrencinin kullanımına sunulan teknik/teknolojik alt yapı ve donanımın yeterliliği hakkındaki görüşleri sorulmuştur. Bu önermede de bir öncekinde olduğu gibi tepe değer (5) 158 frekanstır ve merkezi eğilim ortalaması 3,99'dur. Örneklemin uygulamalı derslerde olduğu gibi teknolojik alt yapının yetersizliği konusunda da benzer kanaatlere sahip olduğu anlaşılmaktadır?

Gazetecilik eğitiminde mesleğe ilişkin dersler yeterlidir önermesinin tepe değeri (4) 144 frekanstır. Merkezi eğilim ortalaması ise 3,58'dir. Gazetecilik formasyonunun interdisipliner karakterinden dolayı ders programında yer verilen temel derslerin (ekonomi, hukuk, sosyoloji, işletme gibi) doğrudan mesleğe yönelik olmadığının düşünülmesi, entelektüel bir zemin oluşturmaya hizmet ettiklerinin anlaşıl(a)maması ve mesleki derslere geçiş hazzını ertelenmesi gibi nedenlerle öğrenci nezdinde "gereksiz"miş gibi algılanmaları söz konusu olabilmektedir. Araştırma bulguları da bir yönüyle bunu doğrulamaktadır. Bu bulgu meslek dışı derslerin gereksiz görüldüğü şeklinde değil ancak örneklemin önemli bir bölümünün mesleki ders oranını yeterli bulmadıklarını şeklinde yorumlanabilir.

Eğitim ve sektör ilişkisine ilişkin bulgular ise şöyledir:

E.Ü. İletişim Fakültesi'nde öğrenciler, mezun olmadan önce (genellikle 3. sınıf yazında) bir medya kuruluşunda en az 20 iş günü staj yapmak ve bunu belgelemek durumundadırlar ${ }^{8}$. Staj süreci hem mesleki deneyim için bir imkân hem de mezuniyet

7 Ancak 2010 yılı mezunları ile örneğin 2016 yılı mezunlarına sunulan teknolojik alt yapı ve donanımın da aynı olmadığı, dolayısıyla görüşlerin mezuniyet yılı koşullarını yansıtabileceği hatırlatılmalıdır.

8 Ayrıca kurum içi uygulama birimi olan Ege Ajans'ta da 3. ve 4. sınıfların her döneminde bir hafta (5 iş günü) 
sonrası öğrencinin bir iş bağlantısı oluşturabilmesi açısından bir fırsat olarak görülmektedir. Ancak staj sürecinde, eğitim sürecinde tecrübe edilmesi mümkün olmayan mesleki pratiklere ilişkin olumlu/olumsuz tanıklıklar, staj deneyiminin duygusal motivasyonları ya da handikapları, gazeteciliği benimsemeyi kolaylaştırabileceği gibi güçleştirebilmektedir de. Profesyonellerin stajyerliği mesleğe adaptasyon ve mesleki eğitimin bir parçası olarak değerlendirmeden ziyade stajyer öğrencileri bir ayak bağı olarak görerek amaç dışı 'getir, götür' işlerinde kullanmaları, stajyer öğrencilerin motivasyonlarını kırmakta ve mesleğe bakışlarını olumsuz yönde değiştirmektedir (Yıldırım, 2006: s. 138). Araştırmada kurum dışı staj deneyiminin, öğrencinin gazetecilik mesleğini yapıp yapmama konusundaki kararları üzerinde etkili olabildiği gözleminden yola çıkılarak, örnekleme kurum dışı staj mesleğe katıımı teşvik etmektedir önermesi sunulmuştur. Bu önermeye ilişkin tepe değer (2) 185 frekansa sahiptir. Merkezi eğilim ortalama değeri 2,22'dir. Bu bağlamda örneklem açısından kurum dışı stajın, ağırlıklı olarak eğitim sürecinin gerekli ve tamamlayıcı bir parçası olarak görüldüğü anlaşılmaktadır.

Gazetecilik eğitimi sektörün taleplerini karşılamaktadır önermesinin tepe değeri (4) 134 frekans, merkezi eğilim ortalaması 3,66'dır. Örneklemin bu önerme konusundaki merkezi eğilimi, eğitimin sektör beklentilerini karşılamadığı yönünde ağırlık kazanmaktadır.

Türkiye'deki tüm iletişim fakültelerinde olduğu gibi, Ege Üniversitesi'nde de gazetecilik eğitimi veren akademik personelin bir kısmı sektör deneyimine sahipken, bir kısmı değildir. Ancak sahadan uzak kalınması ya da değişip dönüşen teknolojiler ve iş pratikleri anlamında güncellen(e)memesi durumunda sektör deneyimi de eğitim açısından kullanışlı vasfını zaman içinde yitirebilmektedir. Bu durum, özellikle mesleki pratikle ilişkili derslerde öğrenci için de akademik personel için de bir handikap oluşturmaktadır. Eğitimcilerin sektör deneyimine sahip olup olmamasının öğrencilerin gözünde bir fark yaratıp yaratmadığını anlamak üzere örnekleme gazetecilik alanındaki eğitimcilerin sektörel tecrübeye sahip olması şarttır önermesi sunulmuştur. Tepe değeri (1) 201 frekans olarak hesaplanan önermede merkezi eğilim ortalaması 1,74'tür. Buna göre, eğitimcilerin sektör deneyimine sahip olmasının bir gereklilik olduğu görüşü ağırlık kazanmaktadır. Bu beklenti, uygulamalı derslerin daha fazla olmasına duyulan intiyaç, teknik/teknolojik imkânların ve mesleki derslerin yetersiz olduğu yönündeki kanaatler ve eğitimin sektörün beklentilerini karşılamadığı yönündeki görüşlerle birlikte okunduğunda anlamlıdır. Öğrencinin mesleki becerileri destekleyecek dersler ve donanım yanında bunu aktarabilecek, akademik bilgiyi sektör deneyimi ile birleştirebilen bir eğitimci profili görmek istediği anlaşılmaktadır.

Gazetecilik lisansı, öğrenciler tarafından genellikle farklı şekillerde sürdürülmektedir. Bazıları 4 yıl boyunca sadece derslere katılıp yüksek ortalama ve akademik kariyer planı yaparken, bazıları sektöre adım atarak acemiliği erken atma yolunu seçebilmektedir. Sadece sınavlara girerek sahada başarıyı yakalayanlar, yüksek not otamalarına rağmen sektöre çıktığında deneyimsizlik gerçeğiyle yüzleşenler, lisansı tamamlayıp sonrasında kendine tamamen farklı rota çizen örnekler sıklıkla rastlanabilen profill- 
erdir. Bu bağlamda, örnekleme gazetecilik eğitimi sırasında sektörde çalışmak sonrası için önemli bir avantajdır önermesine ilişkin görüşleri sorulmuştur. Tepe değer (1) 250 frekans, merkezi eğilim ortalaması 1,48 olarak hesaplanmıştır. Buna göre örneklemin görüşleri, öğrencilikteki sektör deneyiminin mezuniyet sonrası iş bulmada büyük bir avantaj oluşturduğu yönünde ağırlığa sahiptir.

Gazetecilik mesleği ve sektöre ilişkin görüşler: Örnekleme gazetecilik mesleği ve sektörle ilgili bazı önermeler verilerek, katılım düzeyleri sorulmuştur. Bulgular Tablo 6.'da görülmektedir.

Tablo 6. Gazetecilik Mesleği ve Sektöre Illişkin Görüşler

Kesinlikle katılıyorum:1 Katılıyorum:2 Fikrim Yok:3 Katımıyorum:4 Kesinlikle Katılmıorum:5

\begin{tabular}{|l|c|c|c|c|c|c|c|}
\hline $\begin{array}{l}\text { Gazetecilik mesleği ve } \\
\text { sektörle ilgili aşağıdaki } \\
\text { görüşlere hangi düzeyde } \\
\text { katııısınız? }\end{array}$ & 1 & 2 & 3 & 4 & 5 & $\begin{array}{c}\text { Tepe } \\
\text { Değer }\end{array}$ & $\begin{array}{c}\text { Or- } \\
\text { talama } \\
\text { (Mean) }\end{array}$ \\
\cline { 2 - 7 } $\begin{array}{l}\text { Mesleğe girişte gazetecilik } \\
\text { bölümü mezunu olma şartı } \\
\text { mutlaka aranmalıdır }\end{array}$ & 227 & 84 & 7 & 47 & 12 & 1 & 1,77 \\
\hline $\begin{array}{l}\text { Mesleğe dışarıdan girişler, } \\
\text { gazetecilik mezunlarını iş } \\
\text { olanaklarını daraltmaktadır }\end{array}$ & 278 & 68 & 9 & 16 & 6 & 1 & 1,42 \\
\hline $\begin{array}{l}\text { Gazetecilik tehlikeli bir } \\
\text { meslektir }\end{array}$ & 111 & 156 & 27 & 59 & 25 & 2 & 2,29 \\
\hline $\begin{array}{l}\text { Türkiye'de gazetecilik yap- } \\
\text { mak risklidir }\end{array}$ & 217 & 126 & 17 & 9 & 9 & 1 & 1,59 \\
\hline $\begin{array}{l}\text { Gazeteciliği yurt dışında } \\
\text { yapmayı tercih ederdim }\end{array}$ & 163 & 107 & 56 & 43 & 8 & 1 & 2,01 \\
\hline $\begin{array}{l}\text { Gazetecilik onurlu bir } \\
\text { meslektir }\end{array}$ & 228 & 89 & 33 & 18 & 10 & 1 & 1,66 \\
\hline $\begin{array}{l}\text { Çocuğumun gazeteci } \\
\text { olmasını isterim }\end{array}$ & 37 & 72 & 99 & 61 & 109 & 5 & 3,35 \\
\hline
\end{tabular}

Gazetecilik sadece gazetecilik eğitimi almış kişiler değil, farklı formasyona sahip ancak alana ilgi duyan kişilerce de yapılabilmektedir. Geleneksel pratikte gazetecilik eğitimi almış (mektepli) ya da "mutfaktan" yetişmiş (alaylı) çekişmesi olarak tecrübe edilen bu durum mesleki dönüşümle birlikte kısmen geçerliliğini yitirmiş kısmen de yeni bir form almıştır. Bu bağlamda örnekleme mesleğe girişte, gazetecilik mezunu olma şartı mutlaka aranmalıdır önermesine katılım düzeyleri sorulmuştur. Bu önermeye ilişkin tepe değeri (1) 227 frekans, merkezi eğilim ortalaması 1,77 olarak hesaplanmıştır. Mesleğe zor şartlarda adım atan ve yakın zamana kadar alaylı-mektepli çekişmesiyle yüz yüze olan mezunların bu önermeye ilişkin merkezi eğilimi, mesleğe girişte gazetecilik mezunu olma şartının aranması gerektiği yönünde ağırıı kazanmaktadır. 
Mesleğe dışarıdan girişler, gazetecilik mezunlarının iş olanaklarını daraltmaktadır önermesinin tepe değeri (1) 278 frekans ve merkezi eğilim ortalaması 1,42'dir. Yani, örneklemin önemli bir çoğunluğu mesleğe gazetecilik dışı alanlardan katılımın iş olanaklarını daralttığı görüşünde birleşmektedir. Mesleğe dışarıdan katılanlar sadece alaylıları değil, farklı formasyonlardan gelenleri de kapsamaktadır. Fakat gazeteciliğin ilgi, merak gibi motivasyonlar ve düzensiz bir yaşam biçimiyle başa çıkabilmek gibi formasyona bağlı olmayan "nitelikler" gerektirmesi, ister istemez eğitimini aldığı halde mesleği icra edemeyen, buna mukabil eğitimini almadığı halde mesleği icra etmeye yatkın profilleri olası kılmaktadır. Bu bağlamda kurumların tercihi gazetecilik eğitimi aldığı halde mesleğe "meraksız ve isteksiz" mezundan ziyade, eğitimini almasa da yüksek motivasyonla yani "hevesle ve cefakârca" çalışabilecek profilden yana olabilmektedir.

Türkiye ve dünya örneğinde risk faktörleri dikkate alınarak, gazeteciliği ne düzeyde "tehlikeli" bir meslek olarak algıladıklarını anlamak üzere örnekleme gazetecilik tehlikeli bir meslektir önermesi sunulmuştur. Bu önermenin tepe değeri (2) 156 frekans, merkezi eğilim ortalaması ise 2,29 olarak hesaplanmıştır. Buna göre örneklem, gazeteciliğin "tehlikeli" bir meslek olduğu yönünde ağırlıklı görüş bildirmiştir.

Bu soru genel olarak mesleğin genel riskleri düşünülerek yanıtlanmış olabileceğinden, bir sonraki önerme Türkiye'de gazetecilik yapmak risklidir şeklinde inceltilerek sunulmuştur. Bulgulara göre tepe değer (1) 217 frekans, merkezi eğilim ortamalası 1,59'dur. Araştırmaya katılanlar gazeteciliği genel olarak "tehlikeli” bir meslek olarak görmelerinin yanı sıra Türkiye'de gazetecilik yapmanın "riskli” olduğu görüşüne daha yüksek bir katılım göstermişlerdir. Bu algıda, Türkiye gazetecilik tarihindeki suikastlar, kayıp vakaları, baskı ve sansür politikaları gibi bugün de devam eden ve gözlenen tecrübelerin etkili olduğu düşünülebilir. Örneklemin de içinde yer aldığı yani 2000'lerin başından bugüne gelişen süreç düşünüldüğünde, gazeteciler üzerinde ağırlaşan baskılar, ifade özgürlüğü kısıtlamaları, gözaltı, tutuklama ve uzun süreli yargılamalar, eğitim sürecinde de mezun olduktan sonra da mesleğin tehlikeli bir alanda -yine deyim yerindeyse "at sürmek"- olarak görüldüğünü ortaya koymaktadır. Türkiye medyasının 2002-2012 yıllarını değerlendiren Çam ve Yüksel'e (2015: s. 70-71) göre bu süreçte, "politik görüşleri ne olursa olsun AKP'ye muhalif her gazeteci, köşe yazarı, televizyon programı yapımcısı ve sunucusu üzerinde giderek artan bir baskı, işini kaybetme, mesleğin dışına itilme ve itibarsızlaştırılma tehdidi vardır ve bu tehdit defalarca da gerçekleşmiştir".

Gazeteciliği yurt dışında yapmak isterdim önermesi, bir önceki önermeye ilişkin görüşleri boyutlandırmak amacıyla sunulmuştur. Örneklemin bu önermeye ilişkin tepe değer (1) frekansı 163, merkezi eğilim ortalaması ise 2,01'dir. Bu bulguya göre Türkiye koşullarında "riskli" olarak algılanan mesleğin, yurt dışında daha uygun koşullarda icra edilebileceğine ve bu olasılıkta tercih edilebileceğine ilişkin kanaat ağırlık kazanmaktadır. Journo'dan Seda Karatabanoğlu'nun (2019) Avrupa merkezli bir uluslararası yayın kuruluşunun Türkiye vatandaşı muhabiriyle yaptığı görüşme bu bulgularla örtüşen bir gerçeği dile getirmektedir: 
Türkiye dışında gazetecilik yapıyor olmak, belli bir güvence veriyor. Misal, sabahın 5'inde gözaltına alınmayacağımı biliyorum. Ama bu, elbette ki radarda olmadığımız anlamına gelmiyor. Yine de Türkiye'deki meslektaşlarımızın aksine siyasi baskıdan uzak işimizi yapıyor olmak bugün için büyük şans ve lüks.

Türkiye'de medyanın son dönemde ciddi bir güven erozyonu yaşadığı da bilinmektedir. Reuters Gazetecilik Çalışmaları Enstitüsü'nün Türkiye raportörü Servet Yanatma'ya (2018) göre, 2018'de medyaya \% 38 güven ve \% 40 güvensizlik söz konusudur ve birbirine yakın orandaki bu bulgular kutuplaşmış toplumun işaretidir. 2019 raporunda ise (Yanatma, 2019), önceki yıllara kıyasla genel olarak haberlere güvende 8 puanlık bir artış (\% 46) olsa da bunun net bir açıklaması yapılamamış, hükümet yanlısı medyaya daha az güvenildiği fakat bu medyayı kullananlardan daha yüksek puanlar alındığını ifade edilmiştir.

Gazeteciliğe ilişkin bu güven kaybının, mezunların kendi mesleklerine bakışlarında bir etkisi olup olmadığını anlamak üzere katılımcılara, gazetecilik onurlu bir meslektir şeklinde bir önerme sunulmuştur. Bu önermeye ilişkin tepe değer (1) 228 frekans ve merkezi eğilim ortalaması 1,66'dır. Bu bulgu, her şeye rağmen gazeteciliğin yapıldığı coğrafya, politik koşullar, kötü örnekler bir yana bırakıldığında kendinden menkul bir değeri olduğunu ve mesleki ilkelere bağlı, dürüstçe icra edilen "onurlu gazeteciliğin" halesinin öğrenci nezdinde muhafaza edildiğini düşündürmektedir.

Son olarak çocuğumun gazeteci olmasını isterdim ${ }^{9}$ önermesine ilişkin kanaatler ölçülmüştür. Tepe değer (5) frekansı 109 olan örneklemin, 3,35 merkezi eğilim ortalamasıyla bu önermeye katılmadıkları ancak önemli bir bölümünün de bir fikrinin olmadığı görülmüştür. Buna göre gazetecilik, kuşaklar arasında devamlıı̆ı arzulanan bir meslek olarak görülmemektedir.

Mesleki yönelime göre dağılım: Araştırmaya katılanlara şu andaki mesleklerinin gazetecilik alanında olup olmadığı sorulmuştur. Tablo 7.'de görüldüğü gibi mezunların \% 72,2'si (273) bu soruya hayır gazetecilik yapmıyorum; \% 27,8'i ise (105) evet gazetecilik alanında çalışıyorum yanıtını vermişlerdir.

Tablo 7. Mesleki Yönelime Göre Dağılım

\begin{tabular}{|l|c|c|}
\hline Şu anki mesleğiniz gazetecilik alanında mı? & $\mathbf{f}$ & $\%$ \\
\hline Evet gazetecilik alanında çalışıyorum & 105 & 27,8 \\
\hline Hayır gazetecilik alanında çalışmıyorum & 273 & 72,2 \\
\hline Toplam & $\mathbf{3 7 8}$ & $\mathbf{1 0 0}$ \\
\hline
\end{tabular}

Araştırmanın buraya kadar olan bölümünde mezunların gazetecilik eğitimi ve gazetecilikle ilgili genel görüşlerine ilişkin bulgulara yer verilmiştir. Bu aşamadan itibaren araştırma örneklemi ikiye ayrılmıştır. Hâlihazırda gazetecilik yapanlarla, yapmayanlar farklı soru gruplarına yönlendirilmiştir. 


\subsection{Mesleki Yönelimi Gazetecilik Olan Katılımcılara Illișkin Bulgular}

$\mathrm{Bu}$ bölümdeki bulgular, gazetecilik alanında çalışan 105 kişiye, yani örneklemin \% 27,8'ine ilişkindir. Bu popülasyonun cinsiyet dağılımı 39 kadın, 66 erkek şeklindedir. Mesleği icra edenler arasında erkek popülasyon ağırlıktadır.

Gazetecilik yapanların çalıştıkları kurum: Örnekleme, boş bırakma seçeneği de sunularak çalıştıkları kurumun adı sorulmuştur. Ancak büyük bir çoğunluk cevabı boş bırakmıştır. Bu bağlamda anlamlı bir yorum yapılamayacağından bu soruya ilişkin bulgular araştırma dişında tutulmuştur.

Gazetecilik mesleğini yapanların çalıştığı alanlar: Gazetecilik yapanların hangi alanda çalıştığı Tablo 8.'de görülmektedir.

Tablo 8. Gazetecilik Yapanların Çalıştığı Alanlar

\begin{tabular}{|l|c|c|}
\hline Hangi alanda gazetecilik yapıyorsunuz? & $\mathbf{f}$ & $\%$ \\
\hline Kamu yayıncılığı kurumlarında & 2 & 1,9 \\
\hline Kamu basın halkla ilişkilerde & 4 & 3,8 \\
\hline Özel sektör basın halkla ilişkilerde & 9 & 8,6 \\
\hline Özel sektör ulusal TV/gazete/dergide & 20 & 19 \\
\hline Özel sektör haber ajansı bünyesinde & 10 & 9,5 \\
\hline Özel bir internet haber/blog sitesinde & 13 & 12,4 \\
\hline Kendi kurduğum haber/blog sitesinde & 3 & 2,9 \\
\hline Yerel TV/gazete/dergide & 35 & 33,3 \\
\hline Reklam ajansı bünyesinde & 4 & 3,8 \\
\hline Diğer & 5 & 4,8 \\
\hline Toplam & $\mathbf{1 0 5}$ & $\mathbf{1 0 0}$ \\
\hline
\end{tabular}

Tabloya göre, gazetecilik yapanların \% 33,3'ünün (35) yerel TV/gazete/dergi kategorisinde yoğunlaştığı görülmektedir. \% 19'u (20) özel sektör ulusal TV/gazete/ dergi ve \% 12,4'ü de (13) özel bir internet haber/blog sitesinde çalışmaktadır. Özel sektör haber ajansı bünyesinde çalışan \% 9,5 (10) katılımcı mevcuttur. Genel olarak değerlendirildiğinde yerel oluşumların bir istihdam sahası olmayı sürdürdükleri hatta bu konuda öncülüğü üstlendikleri söylenebilir.

Gazetecilik mesleğinde bulunulan pozisyonlar: Gazetecilik yapanların çalıştığı kurumdaki pozisyonları gösteren tablo ise şöyledir:

Tablo 9. Gazetecilik Alanında Bulunduğu Pozisyon

\begin{tabular}{|l|c|c|}
\hline Bulunduğunuz pozisyon? & $\mathbf{f}$ & $\%$ \\
\hline Yayın/ajans/haber sitesi sahibi & 3 & 2,9 \\
\hline Yazı işleri sorumlusu/müdürü & 4 & 3,8 \\
\hline Genel yayın yönetmeni & 3 & 2,9 \\
\hline Muhabir & 42 & 40 \\
\hline İstihbarat & 1 & 1 \\
\hline Kameraman & 1 & 1 \\
\hline Görsel yönetmen & - & - \\
\hline
\end{tabular}




\begin{tabular}{|l|c|c|}
\hline Sayfa sekreteri & 3 & 2,9 \\
\hline Grafik tasarım & 2 & 1,9 \\
\hline Editör & 30 & 28,6 \\
\hline Yazı işleri & 3 & 2,9 \\
\hline Köşe/blog yazarı & 1 & 1 \\
\hline Reklam/satış & 1 & 1 \\
\hline İari birim & - & - \\
\hline Diğer & 11 & 10,5 \\
\hline Toplam & $\mathbf{1 0 5}$ & $\mathbf{1 0 0}$ \\
\hline
\end{tabular}

Tablo 9.'a göre, gazetecilik alanında çalışanların mesleki pozisyonları \% 40 oranıyla (42) muhabir pozisyonunda ağırlık kazanmakta; ardından \% 28,6 (30) oranıyla editörlük gelmektedir. Muhabir olarak çalışanların 16'sı kadın, 26'sı erkek; editör pozisyonunda çalışanların ise 13'ü kadın, 17'si erkektir.

Gazetecilik mesleğini sürdürme eğilimi: Mesleği gelecekte sürdürme eğilimlerini anlamak üzere araştırmaya katılanlara Tablo 10'da görülen önermeler sunulmuş ve en yakın oldukları önermeyi işaretlemeleri istenmiştir.

Tablo 10. Gazetecilik Mesleğini Sürdürme Eğilimi

\begin{tabular}{|l|c|c|}
\hline $\begin{array}{l}\text { Aşağıdaki ifadelerden kendinizi en yakın hissettiğinizi } \\
\text { işaretleyiniz }\end{array}$ & f & $\%$ \\
\hline $\begin{array}{l}\text { Gazeteciliği seviyorum, başka bir iş yapmayı hiçbir koşulda } \\
\text { düşnmüyorum. }\end{array}$ & 261 & 24,8 \\
\hline $\begin{array}{l}\text { Gazeteciliği seviyorum, ancak şartlar gerektirirse başka bir işe } \\
\text { geçebilirim }\end{array}$ & 9 & 8,6 \\
\hline $\begin{array}{l}\text { Bir süre gazetecilik yaptıktan sonra başka bir işe geçmeyi } \\
\text { düşünüyorum }\end{array}$ & 6 & 5,7 \\
\hline Daha iyi bir iş bulamadığım için zorunluluktan yapıyorum & 1 & 1. \\
\hline $\begin{array}{l}\text { Uzun süredir tatmin edici bir pozisyonda ve güvencede } \\
\text { olduğum için yapıyorum }\end{array}$ & 2 & 1,9 \\
\hline $\begin{array}{l}\text { Gazeteciliği kişisel hevesimi tatmin edecek bir ek iş olarak } \\
\text { yapıyorum }\end{array}$ & 105 & 100 \\
\hline Toplam & $61 \%$ \\
\hline
\end{tabular}

Önermeler arasında tepe değer bakımından öne çıkan seçenek, 61 frekansla (\% 58) gazeteciliği seviyorum, ancak şartlar gerektirirse başka bir işe geçebilirim olmuştur. Bu seçeneği işaretleyenlerin cinsiyet dağılımı çapraz tablo analizi bulgularına göre 19 kadın, 42 erkek şeklindedir. Gazeteciliği seviyorum, başka bir iş yapmayı hiçbir koşulda düşünmüyorum diyenlerin oranı ise \% 24'tür (26). Cinsiyet dağılımı bakımından bu seçeneği tercih edenlerin 14'ü kadın, 12'si erkek katılımcıdır. Tablo 10. yorumlandığında gazetecilik mesleğini vazgeçilmez bir meslek olarak gören ve sürdürme eğilimi sergileyenlerin oranı oldukça düşüktür. Gazetecilik, bir süre icra edildikten sonra çeşitli saiklerle (mesleki pratikte ya da özlük haklarında karşılaşılan problemler) geçiş yapılacak bir meslek haline dönüşmüş görünmektedir. 
Gazetecilik mesleğinde iş değiştirme sıklığı: Katılımcıların gazetecilik yaptıkları süre boyunca kaç kez iş değiştirdikleri Tablo 11.'de görülmektedir:

Tablo 11. Gazetecilik Mesleğinde İş Değiştirme Dağılımı

\begin{tabular}{|l|c|c|}
\hline $\begin{array}{l}\text { Gazetecilik mesleğinde } \\
\text { kaç kez iş değiştirdiğiniz }\end{array}$ & $\mathbf{f}$ & \% \\
\hline Hiç değiştirmedim & 41 & 39 \\
\hline 1-3 kez değiştirdim & 52 & 49,5 \\
\hline 3'ten çok değiştirdim & 12 & 11,4 \\
\hline Toplam & $\mathbf{1 0 5}$ & $\mathbf{1 0 0}$ \\
\hline
\end{tabular}

Bulgulara göre gazetecilik alanında geçen süre boyunca katılımcıların \% 49,5’i (52) 1-3 kez iş değiştirmişlerdir. Burada anlamlı bir yorum yapmak, işe henüz yeni başlamış olanların iş değiştirme olasılıklarının düşük olması nedeniyle sağlıklı olmayacaktır.

İş değiştirme nedenleri: Katılımcılara en çok 5 seçenek işaretleyebilecekleri belirtilerek iş değiştirme nedenleri sorulmuştur. Bu soru Tablo 11.'de 1-3 kez ve 3'ten fazla iş değiştirdiğini belirten toplam \% 60,9'luk (64) örnekleme yöneliktir. Seçenekler üzerinde toplam 152 işaretleme yapmışlardır.

Tablo 12. Gazetecilik Alanında İş Değiştirme Nedenleri

\begin{tabular}{|l|c|c|}
\hline $\begin{array}{l}\text { İş değiştirme nedenleriniz neydi? } \\
\text { (En çok 5 seçenek) }\end{array}$ & $\mathbf{f}$ & $\%$ \\
\hline Ekonomik gerekçelerle işten çıkarılmak & 18 & 26,9 \\
\hline Politik görüşüm nedeniyle işten çıkarılmak & 3 & 4,5 \\
\hline Yayın organının kapanması & 9 & 13,4 \\
\hline Ücret yetersizliği & 42 & 62,7 \\
\hline Sigortasız çalıştırımak & 16 & 23,9 \\
\hline Yönetimle fikir uyuşmazlığı & 14 & 20,9 \\
\hline Çalışma ilişkilerine uyum sağlayamamak & 5 & 7,5 \\
\hline $\begin{array}{l}\text { Ayrımcı uygulamalara (cinsel, etnik, dini } \\
\text { vb.) maruz kalmak }\end{array}$ & 5 & 7,5 \\
\hline Mobbing & 10 & 14,9 \\
\hline Daha iyi bir iş bulmak & 24 & 35,8 \\
\hline Diğer & 6 & 9,5 \\
\hline
\end{tabular}

Tablo 12.'de görüldüğü üzere tepe değer bakımından en sık iş değiştirme nedeni 42 frekans değeri ile ücret yetersizliğidir. İkinci sırada 24 frekansla daha iyi bir iş bulmak ve ardından 18 frekansla ekonomik gerekçelerle işten çıkarılmak seçenekleri yer almaktadır. Bulgular yorumlandığında, gazetecilik yapanların iş değişikliklerindeki temel nedenin ekonomik faktörlere dayandığı görülmektedir. Ücret yetersizliği ya da daha iyi bir iş bulmak, meslektekilerin kendi iradeleriyle gündeme gelen iş değiştirme nedenleri gibi görünse de yine ekonomik kökenlidir ve Türkiye şartlarında "daha iyi bir 
iş" genellikle "maddi imkânları daha iyi" iş anlamına gelmektedir. Ekonomik gerekçelerle işten çıkarılmak ise irade dışı bir ekonomik neden olarak iş değişikliklerine sebep olmaktadır. Bu minvaldeki iş değişikliklerine, kurumların küçülme politikaları, "maliyet azaltma stratejileri" (az sayıda insana daha fazla iş yüklemek gibi) ya da işletmelerin faaliyetlerine son vererek sektörden çekilmeleri neden olabilmektedir. Ekonomik gerekçeler, Tablo 10.'da tartışılan mesleği sürdürme eğilimlerini de büyük ölçüde etkilemektedir.

Gazetecilik yapanların mesleki pratiğe ilişkin görüşleri: Mesleki pratikte irade beyanında ne derecede "özgür" olunduğu (inisiyatif kullanma, politik görüşlerini açıklıkla ifade edebilme vb), güvencesizlik hissinin hangi noktalarda açığa çıktığı, kaygıları tetikleyen faktörlerin neler olduğu, meslekte ilkelerin mi yoksa ekonomik kaygıların mı öncelikli olduğunu anlamak üzere katılımcılara Tablo 13.'teki önermeler sunulmuştur.

Tablo 13. Gazetecilik Yapanların Mesleki Pratiğe İlişkin Görüşleri

Kesinlikle katılıyorum:1 Katılıyorum:2 Fikrim Yok:3 Katılmıyorum:4 Kesinlikle Katılmıyorum:5

\begin{tabular}{|l|c|c|c|c|c|c|c|}
\hline $\begin{array}{l}\text { Mesleki tecrübenizi ve } \\
\text { çalışma koşullarınızı göz } \\
\text { önüne alarak, aşağıdaki } \\
\text { görüşlere hangi düzeyde } \\
\text { katılığınızı belirtiniz }\end{array}$ & $\mathbf{1}$ & $\mathbf{2}$ & $\mathbf{3}$ & $\mathbf{4}$ & $\mathbf{5}$ & $\begin{array}{c}\text { Tepe } \\
\text { Değer } \\
\text { (Mode) }\end{array}$ & $\begin{array}{c}\text { (f) } \\
\text { Orta- } \\
\text { (Mala } \\
\text { (Mean) }\end{array}$ \\
\hline $\begin{array}{l}\text { Iş̧imde sadece benden bekle- } \\
\text { neni yaptı̆̆ım sürece güvende } \\
\text { hissediyorum }\end{array}$ & 27 & 40 & 8 & 25 & 5 & 2 & 3,37 \\
\hline $\begin{array}{l}\text { Politik görüşlerimi gizlediğim } \\
\text { sürece güvende hissediyorum }\end{array}$ & 13 & 27 & 15 & 36 & 14 & 4 & 3,10 \\
\hline $\begin{array}{l}\text { Mesleki haklardan yoksun } \\
\text { olduğum için güvende hisset- } \\
\text { miyorum }\end{array}$ & 36 & 37 & 11 & 15 & 6 & 2 & 2,22 \\
\hline $\begin{array}{l}\text { Politik görüşlerimi her ortamda } \\
\text { çekinmeden ifade edebilirim }\end{array}$ & 26 & 40 & 10 & 17 & 12 & 2 & 2,51 \\
\hline $\begin{array}{l}\text { Politik görüşlerime uygun olma- } \\
\text { yan bir kurumda çalışabilirim }\end{array}$ & 14 & 32 & 21 & 24 & 14 & 2 & 2,92 \\
\hline $\begin{array}{l}\text { Maddi zorunluluklar nedeniyle } \\
\text { inanmasam da benden bekle- } \\
\text { nen işi yaparım }\end{array}$ & 8 & 36 & 21 & 26 & 14 & 2 & 3,02 \\
\hline $\begin{array}{l}\text { Şu anki konumumda gazeteciliği } \\
\text { maddi olarak doyurucu buluyo- } \\
\text { rum }\end{array}$ & 5 & 14 & 4 & 20 & 62 & 5 & 4,14 \\
\hline $\begin{array}{l}\text { Gazeteciliği sosyal ve politik } \\
\text { prestij için yapıyorum }\end{array}$ & 4 & 23 & 12 & 32 & 34 & 4 & 3,66 \\
\hline $\begin{array}{l}\text { Çocuğumun da gazeteci } \\
\text { olmasını isterim }\end{array}$ & 10 & 17 & 32 & 16 & 30 & 3 & 3,37 \\
\hline
\end{tabular}

Tablo 13.'e göre, çalışan gazetecilere yöneltilen işlerinde sadece benden bekleneni 
yaptığım sürece kendimi güvende hissediyorum önermesinin tepe değeri (2) 40 frekanstır. Merkezi eğilim ortalaması ise 3,37'dir. Bu önerme konusunda örneklemin fikrim yok düzeyine yakın bir eğilime sahip olduğu görülmektedir.

Gazetecilik alanında çalışanların politik olarak kendilerini ne düzeyde açıklıkla ifade edebildiklerine ilişkin bulgulardan bazıları ise şöyledir:

Politik görüşlerimi gizlediğim sürece güvende hissediyorum önermesinin tepe değeri (4) 36 frekans ve merkezi eğilim ortalama değeri 3,10'dur. Bulgular fikrim yok yönünde bir eğilimi işaret etmektedir. Örneklemin bu önermeye katılım düzeylerinin sahip oldukları politik görüşe bağlı olup olmadığına bakıldığında muhafazakârların $(3,50)$ ve muhafazakar milliyetçilerin $(3,00)$ ortalama ile katılım yönünün (3) ile $(4)$ düzeyleri arasında yer aldığı görülmektedir. Özellikle muhafazakârların, güvencede hissetmek bakımından politik görüşlerini gizleme eğilimlerinin daha düşük olduğunu anlaşılmaktadır. Ancak liberal/demokrat/sosyal demokratlar $(2,92)$ ile Atatürkçü/Kemalist/Cumhuriyetçilerin $(2,82)$ bu önermeye katılım düzeylerinin (2) ile (3) arasında yer aldığı, dolayısıyla muhafazakâr ve milliyetçilere oranla politik görüşlerini gizleme konusunda daha güçlü bir eğilime sahip oldukları dikkati çekmektedir. Sosyalist/komünist/ devrimci politik görüşlere sahip olanların 3,57 ortalama ile bu önermeye katılmıyor oluşları temsil ettikleri politik görüşün kendini ifade etme anlayışının konjonktürel etkilerden bağımsız olmasıyla açıklanabilir.

Politik görüşlerimi her ortamda çekinmeden ifade edebilirim önermesinin tepe değeri (2) 40 frekansa sahiptir ve merkezi eğilim ortalaması 2,51'dir. Bir önceki önermeye kıyasla, örneklemin politik görüşlerini her ortamda ifade edebilecekleri görüşüne daha yüksek bir katılım gösterdikleri anlaşılmaktadır. Bu eğilim, ifade özgürlüğü nosyonuna yüklenen anlamlarla ve mesleki açıdan bu nosyona bağlılıkla ilişkilendirilebilir. Açıkça söylemek gerekirse, Türkiye bağlamından bağımsız olarak görüşlerini "özgür"ce ifade edebileceğini söylemek mesleğin "şanındandır" ve onurlu gazeteciliğin gereğidir. Öte yandan hiçbir gazetecinin politik görüşlerine otosansür uyguladığını kolaylıkla itiraf edemeyeceği de hesaba katılmalıdır. Bu önermeye de muhafazakârların (2,50), muhafazakâr milliyetçiler ve milliyetçilerin $(2,25)$ ortalama ile katılım eğilimi daha yüksekken, liberal/demokrat/sosyal demokratlar $(3,08)$ ve Atatürkçü/Kemalist/Cumhuriyetçiler $(2,75)$ ortalama ile fikrim yok noktasına daha yakındırlar. Sosyalist/komünist/devrimciler ise politik görüşlerini her ortamda ifade etmek bakımından daha güçlü $(2,25)$ bir eğilime sahiptirler.

Politik görüşlerime uygun olmayan bir kurumda çalışabilirim önermesine ilişkin tepe değer (2) 32 frekans, merkezi eğilim ortalaması 2,92'dir. Bu bulgu, ortalama değer bakımından politik angajmanların mesleği şu ya da bu kurumda yapma kararı üzerinde çok belirgin bir etkisinin olmadığını söylemeye olanak tanımaktadır zira merkezi eğilimin fikrim yok yönünde bir ağırlığa sahiptir. Bu noktada ekonomik gerekçeler ya da mesleğe bağlılığın kararlar üzerinde belirleyici olabileceği söylenebilir. Ortalamalar karşılaştırıldığında, politik görüşlerine uymayan bir kurumda çalışabilme eğiliminin en güçlü olduğu grup muhafazakârlar $(1,50)$ ve milliyetçilerdir $(1,75)$. Bu konuda liberal/ demokrat/sosyal demokratlar $(2,92)$ ile Atatürkçü/Kemalist/Cumhuriyetçiler $(3,11)$ ve sosyalist/komünist/devrimciler $(2,96)$ fikrim yok eğilimine daha yakın durmaktadırlar. 
Maddi zorunluluklar nedeniyle inanmasam da benden beklenen işi yaparım önermesinin tepe değeri (2) 36 frekans ve merkezi eğilim ortalaması 3,02'dir. Dolayısıyla merkezi eğilim bu konuda fikrim yok yönünde ağırlık kazanmaktadır. Maddi zorluklar nedeniyle inanmadığı halde kendisinden bekleneni yapma eğilimi muhafazakârlarda ve muhafazakâr milliyetçilerde 3,50 ortalama ile daha zayıftır. Benzer şekilde sosyalist/ komünist/devrimciler de 3,35 ortalama ile bu önermeye katılmama yönünde daha belirgin eğilime sahiptirler. Liberal/demokrat/sosyal demokratlar $(2,62)$ ile Atatürkçü/Kemalist/Cumhuriyetçilerde $(2,93)$ bu eğilim nispeten daha güçlüdür. Dolayısıyla maddi zorluklar, önerme bağlamında bu iki grubun eğilimleri üzerinde diğer gruplardan daha belirleyici görünmektedir.

Kısa bir özetle, sahip olunan politik görüşün liberal/demokrat/sosyal demokratlar ile Atatürkçü/Kemalist/Cumhuriyetçi görüşlere sahip olanların eğilimleri üzerinde daha belirleyici etkilere sahip olduğu anlaşılmaktadır. Muhafazakârlar, milliyetçi muhafazakârlar ve sosyalist/komünist/devrimciler ortalamalar bakımından bu etkilerden daha uzak görünmektedirler.

Çalışan gazeteciler, güvencesizlik kaygılarını daha net olarak mesleki haklardan yoksun olduğum için güvende hissetmiyorum önermesine verdikleri yanıtlarla ortaya koymuşlardır. Bu önermeye ilişkin merkezi eğilim ortalama değeri 2,22'dir. Tepe değer (2) 37 frekansa sahiptir. Dolayısıyla mesleki haklar bakımından kendini güvencede hisseden ya da çekimser olanların oranı oldukça düşüktür.

Şu anki konumumda gazeteciliği maddi olarak doyurucu buluyorum önermesinin tepe değeri (5) 62 frekans ve merkezi eğilim ortalaması 4,14'tür. Katılmama yönünde oldukça güçlü bir eğilimi yansıtan ve "malumun ilamı" olarak değerlendirebileceğimiz bu bulgu ise hali hazırda mesleğin ekonomik olarak tatmin edici olmaktan çok uzak olduğunu bir kez daha doğrulamaktadır. Önermeye katılım oranı ise oldukça düşüktür. Bu da çalışanların çok küçük bir azınlığının maddi açıdan tatmin koşullarda mesleği sürdürdüklerini göstermektedir.

Gazeteciliği sosyal ve politik prestij için yapıyorum önermesine ilişkin tepe değer (4) 34 frekans ve merkezi eğilim ortalaması 3,66'dır. Bu önerme mesleğe yönelik ikincil beklentileri değerlendirmeye yöneliktir. Çalışan gazetecilerin önemli bir çoğunluğu bu önermeye katılmama yönünde ağırlıklı kanaat beyan ederek, mesleği icra ederken sosyal ve politik prestij sağlama beklentisi içinde olmadıklarını ifade etmişlerdir ${ }^{10}$. Bu bulgu dikkate değer ancak uygulamadaki şekliyle tartışmaya açıktır.

Çocuğumun da gazeteciolmasını isterdimönermesine mesleği icra edenlerin yaklaşımı sorulduğunda merkezi eğilim ortalaması 3,37 olarak hesaplanmıştır. 32 frekansla tepe değer (3) bakımından fikrim yok kanaati öne çıkmakla birlikte, örneklemin bu önermeye katılmama yönünde bir ağırlığa sahip olduğu söylenebilir. Dolayısıyla gazetecilik mesleği, gazetecilerin kendi çocuklarının devam ettireceği bir meslek olarak tasavvur etme konusunda kararsızlıktan olumsuz kanaatte doğru bir yönde tutuma sahip

10 Seçkin (2010) özellikle ortaya yakın ve orta altı gelirli ailelerden gelen muhabirlerin gazetecilik mesleğine yönelim nedenleri arasında "mesleğin önemli kişiler, kurumlar, mekânlar gibi güçlü ve etkileyici pek çok şeyi görme olanağı sunması, haber üretiminin sonucunu ve etkilerini bireysel olarak hemen görmenin hazzı, getirdiğ kurumsal saygınlık, vaatkâr ve ayrıcalıklı bir meslek oluşu” gibi gerekçelerin yer aldığını belirtmektedir. Ancak bu araştırma örnekleminde ortaya çıkan sonuç bu değerlendirmeyi geçersiz kılmaktadır. 
oldukları görülmektedir. Bu konuda tersten bir okuma yapan bir araştırmada (Bak ve Eşidir, 2018), ebeveynleri gazetecilik mesleğinde çalışan çocukların gazetecilikle ilgili görüşlerine başvurulmuştur. Araştırmada ebeveynlerinin kendilerini geliştiren, araştıran, güncel haber bilgisine sahip kişiler olmasını avantaj olarak değerlendiren çocuklar, kendilerine zaman ayrılamamasını da dezavantaj olarak ifade etmişlerdir. Ebeveyn mesleği olarak gazeteciliğin okulda ve sosyal hayatta saygınlık yarattığını ancak okul etkinliklerinde çoğu zaman ebeveynlerinin katılamamasından, tatil ve bayramlarda çalışmalarından olumsuz etkilendiklerini dile getirmişlerdir. Çocuk gözüyle baba mesleğinin değerlendirildiği araştırma bulguları tekrar tersten okunduğunda gazetecilerin aynı gerekçelerle mesleği çocuklarına tavsiye etmedikleri düşünülebilir.

\subsection{Mesleki Yönelimi Gazetecilik Olmayan Katılımcılara İlișkin Bulgular}

Bu bölümdeki bulgular, örneklemin gazetecilik mesleği dışı alanlarda istihdam olmuş ve/veya istihdam dışı \% 72,2'lik (273) kısmına ilişkindir. Bu popülasyonun cinsiyet dağılımı 136 kadın, 136 erkek ve 1 diğer şeklindedir.

Gazetecilik yapmayanların mesleki dağılımı: Gazetecilik yapmayanların mesleki dağılımları Tablo 14.'de görülmektedir.

Tablo 14. Gazetecilik Yapmayanların Mesleki Dağııımı

\begin{tabular}{|l|c|c|}
\hline $\begin{array}{l}\text { Gazetecilik yapmıyorsanız } \\
\text { hangi alanda çalışyorsunuz? }\end{array}$ & $\mathbf{f}$ & $\%$ \\
\hline Kamu sektöründe memur & 7 & 2,6 \\
\hline Özel sektörde memur & 27 & 9,9 \\
\hline Kamu sektöründe işçi & 2 & 0,7 \\
\hline Özel sektörde işçi & 75 & 27,4 \\
\hline Part-time geçici işlerde & 23 & 8,4 \\
\hline Kendi kurduğum işte & 12 & 4,4 \\
\hline Baba mesleği & 7 & 2,6 \\
\hline Esnaf/zanaatkar & 4 & 1,5 \\
\hline Çiftçi & 1 & 0,4 \\
\hline Öğrenci & 25 & 9,1 \\
\hline Ev hanımı & 5 & 1,8 \\
\hline İşsiz & 52 & 19 \\
\hline Diğer & 34 & 12,4 \\
\hline Toplam & $\mathbf{2 7 3}$ & $\mathbf{1 0 0}$ \\
\hline
\end{tabular}

Tablo 14.'e göre, gazetecilik dışı alanlarda istihdam olanların öncelikle \% 27,4'ünün (75) özel sektörde işçi statüsünde çalıştığı görülmektedir. \% 19'u (52) ise istihdam dışı yani işsizdir ve bu oran gazetecilik mezunlarının istihdam sorunu gerçeğini bir kez daha ortaya koymaktadır. Yoğunlaşmanın gözlendiği diğer alan, \% 9,9 (27) oranıyla 
özel sektörde memur statüsüdür. Katılımcıların \% 9,1'i (25) ise öğrencidir. Planlı akademik kariyer hedefinin ötesinde mezuniyet sonrası muhtemel işsizlik, askerlik gibi nedenler mezunları lisansüstü eğitime yöneltmektedir. Genel bir kanaat olarak, büyük şehirlerdeki muhtemel iş imkânları ve gündelik yaşam konforu da eğitim gördükleri yerde kalma arzusunu güçlendirmekte ve öğrenciliğin sürdürülmesi bir çıkar yol olarak görülebilmektedir. Part-time geçici işler kategorisinin oranı \% 8,4 (23)'tür. Özellikle mezuniyet sonrası ilk işe girişlerde part-time ve geçici işler önemli bir payı oluşturmaktadır. Tabloda diğer seçeneği de yüksek bir orana sahiptir: \% 12,4 (34) ve bunların hangi iş kategorileri olduğuna aşağıda yer verilmiştir.

Araştırmaya katılanlara şu anda çalıştığınız işin açık ifadesi (öğretmen, polis, satış temsilcisi vb....) sorusuyla, çalıştıkları alandaki mesleki statünün tam karşılığını belirtmeleri istenmiştir. Bulgular katılımcıların aynen ifade ettiği şekliyle şöyledir:

Kamu sektöründe memur: Akademisyen, polis, subay, öğretmen, bilgi-işlemci.

Özel sektörde memur: Yönetici asistanı, grafiker, fotoğrafçı, insan kaynaklarında uzman/muhasebeci, kabin memuru, laboratuar elemanı, ofis yöneticisi, proje müdürü, PTT posta-evrak, satış destek sorumlusu, satış temsilcisi.

Kamu sektöründe işçi: Resepsiyon görevlisi, sosyal hizmet uzmanı.

Özel sektörde işçi: Araştırma görevlisi, banka müşteri temsilcisi, garson, bar işçisi/ barista, çağrı merkezi müşteri temsilcisi, dekorasyon elemanı, dernek görevlisi, dış ticaret/e-ticaret, editör, fotoğrafçı, gemi işçisi, grafik tasarımcı, HiT ajansı-medya ilişkiler, içerik uzmanı, insan kaynakları uzmanı, inşaat iletişim, kameraman, işçi, kasiyer, kitap evi çalışanı, mağaza/market reyon görevlisi, model, müdür yardımcısı, müşteri temsilcisi, ofis elemanı, otel info, pazarlama sorumlusu, reklam ajansı metin yazarı, resepsiyonist, satış destek/koordinasyon/temsilci, sekreter, stand görevlisi, tekniker, tercüman, tezgâhtar, yangın söndürme sistemleri çalışanı, yayın evi editörü, yönetici asistanı.

Part-time geçici işler: Danışma görevlisi, organizasyon görevlisi, dönemsel/yevmiyeli günlük işçi, kamuda geçici işçi, fotoğrafçı, müzisyen, e-ticaret sitesi içerik üreticisi, garson, sekreter, muhasebeci, kasiyer, kitapçı, saha elemanı, reyon görevlisi, satış temsilcisi, tanıtım hostesi.

Kendi kurduğu iş: Bar/cafe/restoran işletmeciliği, dış ticaret/e-ticaret, emlak danışmanlığı, grafik-tasarım, prodüksiyon şefliği.

Baba mesleği: Gözlükçü, elektrik teknikeri, kuyumcu, müteahhit.

Esnaf/zanaatkâr: Otobüs işletmecisi, kitap cafe işletmecisi.

Diğer: Zeytincilik, turist rehberliği, web tasarımı, iş güvenliği uzmanı, avukat, freelance, dijital pazarlama, finans.

Görülen o ki, aynı isim altındaki işler farklı statülerde yapılmaktadır. Gazetecilik alanı dışında çalışanların çok farklı iş kollarında dağılım gösterdikleri dikkati çekmektedir. Bunlar arasında fotoğrafçılık, içerik üreticiliği, grafik tasarım gibi gazetecilikle ilişkili alanlara rastlanabilse de, bunlar işin mahiyeti bakımından gazeteciliğin çok uzağındadır. 
Örneğin fotoğrafçılık yapan birçok mezun ya düğün/doğum fotoğrafçılığına yönelmekte ya da belediyelerin nikâh salonlarında fotoğrafçılık yapmaktadır. İçerik üretimi ya da grafik tasarım alanında çalışanlar ise çoğunlukla belirli firmaların web tasarım işleriyle ilgilenmekte ya da gazetecilikle doğrudan ilgisi olmayan içerikler üretmektedirler. Öte yandan gazetecilik eğitim programlarının bir parçası olarak fotoğrafçılık, grafik tasarımı, içerik üretimiyle ilgili derslerin mezunların istihdam sorununa gazetecilik dışında bir alternatif üretebilecek formasyonu sağladığı anlaşılmaktadır ve bu olumlu bir katkıdır.

Öğrencilik ve/veya mezuniyet sonrası gazetecilik deneyimi: Gazetecilik dışı alanlarda çalışan ya da işsiz durumdaki katılımcıların öğrencilik sürecinde ve/veya mezuniyet sonrası gazetecilik deneyimi bulunup bulunmadığına ilişkin bulgular Tablo 15.'teki gibidir.

Tablo 15. Öğrencilik ve/veya Mezuniyet Sonrası Gazetecilik Deneyimi

\begin{tabular}{|l|c|c|}
\hline $\begin{array}{l}\text { Öğrencilik ve/veya mezuniyet sonrası gazetecilik deneyimi- } \\
\text { nize ilişkin en uygun seçeneği işaretleyiniz }\end{array}$ & f & $\%$ \\
\hline Sadece öğrencilik stajı yaptım & 112 & 41 \\
\hline Sadece öğrenciyken çalıştım & 51 & 18,7 \\
\hline Öğrenciyken de, mezun olduktan sonra da çalışım ve bıraktım & 78 & 28,6 \\
\hline Sadece mezun olduktan sonra bir süre çalıştım ve bıraktım & 18 & 6,6 \\
\hline Hiç gazetecilik deneyimim yok & 7 & 2,6 \\
\hline Diğer & 7 & 2,6 \\
\hline Toplam & $\mathbf{2 7 3}$ & $\mathbf{1 0 0}$ \\
\hline
\end{tabular}

Tabloya göre örneklemin \% 41'inin (112) gazetecilik deneyimi sadece öğrencilik döneminde yaptığı stajla sınırlıdır. Öğrenciyken de, mezun olduktan sonra da çalıştım ve bıraktım diyenlerin oranı ise $\% 28,6$ 'dır (78).

Gazetecilik yapmama kararının netleşmesi: Gazetecilik yapmama kararının mezunlar için hangi noktada netleştiği önemli bir kırılma olarak değerlendirilebilir. Gündelik konuşmalarda, öğrencilerin bir kısmı gazetecilik eğitimi sırasında hayal kırıklığına uğradıklarını belirtmekte (bunların bir kısmı sahaya yönelirken, bir kısmı meslekten vazgeçmektedir); bir kısmı staj sırasında yaşadıklarının etkisiyle meslekten soğumakta, bazıları ise daha baştan istemediği bir eğitim programına kaydolduğu için 4 yılını yapmayacağı bir mesleğin eğitimini alarak harcamaktadır. Araştırmaya katılanlara yöneltilen, gazetecilik yapmayı hiç düşünmüyorsanız, bu kararınız ne zaman netleşti? sorusuna ilişkin bulgular şöyledir:

Tablo 16. Gazetecilik Yapmama Kararının Netleşmesine Iliş̧in Görüşler

\begin{tabular}{|l|c|c|}
\hline $\begin{array}{l}\text { Gazetecilik yapmayı hiç düşünmüyorsanız, bu } \\
\text { kararınız ne zaman netleşti? }\end{array}$ & $\mathbf{f}$ & $\%$ \\
\hline
\end{tabular}




\begin{tabular}{|l|c|c|}
\hline Gazeteciliği kazandığım andan itibaren kararım belliydi & 9 & 3,3 \\
\hline Gazetecilik eğitimi sürecinde & 36 & 13,2 \\
\hline Staj deneyimim sırasında & 16 & 5,9 \\
\hline Öğrenciyken yaşadığım iş deneyimi sırasında & 18 & 6,6 \\
\hline Mezuniyet sonrası iş deneyimim sırasında & 35 & 12,8 \\
\hline Uzun süren işsizlik sürecinin sonunda & 54 & 19,8 \\
\hline Yakın dönemdeki politik ve ekonomik gelişmelerin & 53 & 19,4 \\
\hline gazeteciliği etkisiyle & 35 & 12,8 \\
\hline Bu konuda netleşmiş bir kararım yok & 4 & 1,5 \\
\hline Hatırlamıyorum & 13 & 4,8 \\
\hline Diğer & $\mathbf{2 7 3}$ & $\mathbf{1 0 0}$ \\
\hline Toplam & & \\
\hline
\end{tabular}

Tablo 16.'ya göre, örneklemin \% 19,8'i (54) uzun süren işsizlik sürecinin sonunda, \% 19,4'ü (53) yakın dönemdeki politik ve ekonomik gelişmelerin gazeteciliğe etkisiyle gazetecilik yapmaktan vazgeçmişlerdir. İki seçenekteki yoğunlaşma, yakın dönem politik ikliminin gazetecilik faaliyetleri üzerindeki etkilerinin ve istihdam sorunu gerçeğinin mesleği yapıp yapmama kararında belirleyici olduğunu göstermektedir. Yanı sıra, \% 13,2 (36) oranındaki gazetecilik eğitimi sürecinde yanıtı, \% 12,8 (35) oranındaki mezuniyet sonrası iş deneyimim sırasında yanıtı da bizzat eğitimin ve mesleki pratiğin "caydırıcı" etkileri (kurumlar, aktörler, pratikler bağlamında) olabildiğini işaret etmektedir. Eğitim sürecindeki vazgeçiş çok katmanlıyken, ilk mesleki tecrübeler ise çeşitli vesilelerle ürkütücü, yılgınlık verici olabilmektedir. \% 12,8 (35) oranındaki katılımcının bu konuda netleşmiş bir kararım yok seçeneğini işaretlenmesi ise mesleğe ilişkin umudun korunduğunun bir göstergesi olarak yorumlanabilir.

Gazeteciliği meslek olarak seçmeme nedenleri: En çok 3 işaretleme yapılabileceği belirtilen bu soruda örneklemin toplam işaretleme sayısı 692'dir. Bulgular Tablo 17.'de görülmektedir.

Tablo 17. Gazeteciliği Meslek Olarak Seçmeme Nedenleri

\begin{tabular}{|l|c|c|}
\hline $\begin{array}{l}\text { Gazeteciliği meslek olarak seçmeme nedenleriniz } \\
\text { nelerdir? (En çok 3 seçenek) }\end{array}$ & $\mathbf{f}$ & $\%$ \\
\hline Gazetecilik alanında uygun iș bulamamak & 137 & 50,2 \\
\hline Iș güvencesinin olmaması & 68 & 24,9 \\
\hline Kariyer ve yükselme olanaklarının kıııtlı olması & 38 & 13,9 \\
\hline $\begin{array}{l}\text { Mesleki ve sosyal hakların (basın kartı, sendikal } \\
\text { örgütlenme vb.) verilmemesi }\end{array}$ & 58 & 21,2 \\
\hline Çalıșma şartlarının ağırlığı & 44 & 16,1 \\
\hline Maddi getirisinin düšük olması & 110 & 40,3 \\
\hline Karakterime uygun değil & 4 & 1,5 \\
\hline $\begin{array}{l}\text { Çalıştığım dönemdeki olumsuz iş ilişkileri ve mob- } \\
\text { bing }\end{array}$ & 17 & 6,2 \\
\hline Calıștığım dönemdeki olumsuz mesleki tecrübeler & 22 & 8,1 \\
\hline
\end{tabular}




\begin{tabular}{|l|c|c|}
\hline Çalıșmak istediğim alandaki cinsiyet ayrımcılığı & 5 & 1,8 \\
\hline Politik görüșlerime uygun bir kurum bulamamak & 32 & 11,7 \\
\hline $\begin{array}{l}\text { Gazetecilik yapmanın önündeki engeller (ifade } \\
\text { Özgürlüğü, sansür vb.) }\end{array}$ & 101 & 37 \\
\hline Akademisyenlik hedefimin olması & 32 & 11,7 \\
\hline Ailevi nedenler (aile kurma, çocuk, eş baskısı vb.) & 6 & 2,2 \\
\hline Öğrencilik hayatımın devam etmesi & 6 & 2,2 \\
\hline Diğer & 12 & 4,4 \\
\hline
\end{tabular}

Tabloya göre en çok işaretleme yapılan seçenek \% 50,2 (137) ile gazetecilik alanında uygun iş bulamamaktır. Çapraz tablo analizi bulgularına göre bu seçeneği işaretleyen 137 kişinin politik görüşlerine göre frekans dağılımı şöyledir: 48 Atatürkçü/Kemalist/ Cumhuriyetçi, 25 liberal/demokrat/sosyal demokrat, 22 sosyalist/komünist/devrimci, 6 muhafazakar milliyetçi, 5 milliyetçi, 2 muhafazakar, 1 anarşist. 28 kişi ise politik görüşünü belirtmek istemeyenler ve diğer seçeneğini işaretleyenlerdir.

İkinci sırada \% 40,3 (110) ile maddi getirisinin düşük olması seçeneği yer almaktadır. Bunu işaretleyenlerin 38'i Atatürkçü/Kemalist/Cumhuriyetçi, 19'u liberal/demokrat/sosyal demokrat, 11'i sosyalist/komünist/devrimcidir.

Üçüncü olarak \% 37 (101) oranıyla gazetecilik yapmanın önündeki engeller (ifade özgürlüğü, sansür vb) seçeneğini işaretleyenlerin ise 35 ’ Atatürkçü/Kemalist/Cumhuriyetçi, 21'i sosyalist/komünist/devrimci, 16'sı liberal/demokrat/sosyal demokrattır. 2 anarşist, 2 muhafazakâr ve belirtmek istemeyerek diğer seçeneğini işaretleyen toplam 25 kişi.

Bulgular, gazeteciliğin bir meslek olarak tercih edilmemesindeki nedenin, özellikle son dönemde her zamankinden daha fazla daralan istihdam olanaklarıla ilgili olduğunu ortaya koymaktadır. Özellikle son dönem ekonomik koşullarında bireyi ya da aileyi geçindirecek maddi/manevi koşulları sağlamaya dair fazla vaadi olmayan bir meslek olarak görülmektedir. Gazeteciliğin tercih edilmemesindeki diğer nedenler de yine maddi koşullarla ilgilidir. Yanı sıra yürürlükteki sosyo-politik ve ekonomik koşulların etkileri, gazeteciliği tercih edilir bir meslek olmaktan alıkoymaktadır.

Mevcut işi seçmeye iten nedenler: Son olarak katılımcılara, mevcut mesleklerine neden yöneldikleri sorulmuştur. Bulgular Tablo 18.'de görülmektedir.

Tablo 18. Mevcut İşi seçmeye İten Nedenler

\begin{tabular}{|l|c|c|}
\hline $\begin{array}{l}\text { Sizi mevcut işinizi seçmeye iten nedenler } \\
\text { nelerdir? (En çok 3 seçenek) }\end{array}$ & $\mathbf{f}$ & $\%$ \\
\hline Devlet güvencesi olması & 14 & 6,4 \\
\hline Kariyer hedeflerime daha uygun olması & 69 & 31,7 \\
\hline Karakterime daha uygun olması & 38 & 17,4 \\
\hline Gerçekten yapmak istediğim iş olması & 30 & 13,8 \\
\hline Maddi getirisinin yüksek olması & 83 & 38,1 \\
\hline
\end{tabular}




\begin{tabular}{|l|l|l|}
\hline Çalışma koşullarının hafif/esnek olması & 54 & 24,8 \\
\hline Düzenli bir hayat için uygun olması & 56 & 25,7 \\
\hline Diğer & 59 & 27,1 \\
\hline
\end{tabular}

Tabloya göre gazetecilik dışındaki bir mesleğe yönelimin en önemli gerekçesi, \% 38,1 (83) maddi getirisinin yüksek olmasıdır. \% 31,7 (69) katılımcı bu soruya, kariyer hedeflerime daha uygun olması yanıtını vermiştir. Dikkate değer yanıtlardan bir kaçı da, \% 25,7 (56) ile düzenli bir hayat için uygun olması, \% 24,8 (54) ile çalışma koşullarının hafif/esnek olmasıdır. Düzenli bir hayat için uygun olması özellikle kadınlar tarafından erkeklere oranla daha fazla işaretlenmiştir (33 kadın, 23 erkek) Genel olarak değerlendirildiğinde, gazetecilik dışı mesleki alanlara yönelimde öncelikle ekonomik gerekçeler ve ardından sektörel yapı, mesleki haklar ve yapılabilirlik koşullarındaki açmazlar etkilidir. Eğilimleri çoğunlukla yüksek maddi kazanç, hafif/esnek/iyi çalışma koşulları, düzenli hayat ve kariyer beklentileri yönlendirmektedir. Fakat Tablo 18.'de atlanmaması gereken bir nokta, \% 27,1 (59) oranındaki diğer seçeneğidir. Bu seçeneğin açılımına bakıldığında, beni mutlu etmesi, tasarıma ilgim gibi olumlu birkaç istisna dışında ağırlıklı olarak zorunluluk, mecburiyet, geçim, para kazanma zorunluluğu, işsizlik korkusu, başka iş bulamama şeklinde zaruriyet bildiren ifadelere rastlanmıştır. Dolayısıyla istisnai tercihler dışında gazetecilik alanından "kaçış"ın alternatifi daha iyi koşullarda iş anlamına gelmemektedir. Mezunların önemli bir kısmı (işsiz olanlar dışında) gazetecilik dışında da en az mevcut gazetecilikte karşılaşacakları kadar zorlayıcı ekonomik şartlar ve olumsuz çalışma koşullarına tabidirler. Üstelik çoğu vasıfsız eleman statüsünde çalışmaktadır.

\section{Sonuç}

Araştırma sorularının çoğunun yanıtının ilgili tabloların altındaki değerlendirmelerde verilmiş olması nedeniyle, sonucu bazı çarpıcı bulgular üzerinden kaleme almak yerinde olacaktır.

Araştırmanın genel bulgularına göre gazetecilik eğitimi alan mezunların, başlangıçta mesleki formasyona bilinçli ve iradi bir seçimle yöneldikleri görülmektedir. Genellikle gazetecilik ilk üç tercihleri içinde yer almaktadır. Ayrıca kişilik özelliklerinin uygunluğu (merak ve ilgi), olaylara tanıklık etme isteği gibi niteliklerin bu tercihlerde bir motivasyon unsuru olarak öne çıkması, öğrencilerin hevesli bir başlangıç yaptıklarını düşündürmektedir. Ancak eğitim süreci içinde ve mezuniyetin erken evrelerinde bu hevesi kıran dinamiklerin devreye girdiği anlaşılmaktadır.

Mezunlar eğitim sürecinde görüşlerini "sitemkâr" tonda seslendirseler de, çoğunlukla gazeteciliği eğitimi alınması gereken bir meslek olarak görmekte ve bu eğitimin mesleğe katılımı teşvik ettiğini düşünmektedirler.

Sanılanın aksine kuramsal derslerin ağırlığından edilen şikâyet araştırmada karşılık bulmamaktadır. Bunun yerine kuramsal ve uygulamaların derslerin makul düzeyde ağırlığa sahip olduğu bir eğitim programı beklentisi ortaya çıkmaktadır. Teknolojik donanım ve imkânlar gibi meslek ağırlıklı dersler de yetersiz görülmektedir. Son tahlilde 
gazetecilik eğitiminin sektörün taleplerini karşılamaktan uzak olduğu görüşü de hâkimdir. Bunun yeni medya ve dijital tabanlı derslerin programlarda ağırlık kazanmasıyla giderilebileceği düşünülmektedir.

Yine eğitim sürecinde serzenişlere rastlanmakla beraber, mezunların gazetecilik mesleğine ilişkin hali hazırdaki yapılış şekliyle değil ama bir "ideal gazetecilik" tasavvuru olarak olumlu bir algıları olduğu söylenebilir. Gazeteciliğin "onurlu bir meslek" olduğunu, mesleği yapmak için eğitiminin de şart olduğunu düşünenlerin oranı yüksektir.

Öte yandan Türkiye şartlarında gazeteciliğin "tehlikeli" ve "riskli" bir meslek olduğu, yurt dışında olsa mesleği icra etmek isteyebilecekleri görüşü önemli bir bulgudur. Şu halde, Türkiye'de mesleki koşullardaki her anlamda iyileşme, mezunların mesleğe olan ilgi ve talebini arttırabilir gibi görünmektedir. Elbette sektörde de bir karşılığı olmak koşuluyla.

Mezunlardan mesleki yönelimi gazetecilik olanların çoğu yerel oluşumlarda ve öncelikle muhabir statüsünde çalışmaktadırlar. Çoğunun ekonomik kaynaklı problemleri olup, çok azı maddi açıdan tatminkâr konumlarda bulunmaktadırlar. Mesleğe dair bir ideale sahip oldukları ancak mevcut koşullarda (özellikle mesleki haklar ve ekonomik girdiler) çok uzun süre gazetecilik yapmayı düşünmedikleri anlaşılmaktadır. Gazeteciliği hiçbir koşulda terk etmeyeceklerin oranı yaklaşık 1/4 iken, daha iyi koşullarda mesleklerini değiştirebileceklerini söyleyenlerin oranı katılımcıların yarısından fazladır.

Maddi gerekçeler, mesleki pratiklerde irade beyanının önünde de zaman zaman bir engel oluşturmaktadır. Katılımcıların bir kısmı politik görüşlerini açıklamaktan kaçındıklarını, sadece kendilerden bekleneni yaptıkları sürece iş güvencesine sahip olduklarını hissettiklerini belirtmişlerdir. Maddi ve mesleki haklar sağlandığında, politik angajmanın bir kurumda çalışmanın başat belirleyicisi olmayabileceği düşünülmektedir. Mesleki pratiğin içinde olanların politik görüşleri kendilerini güvencede hissetmeleri noktasında bir değişkene dönüşebilmektedir.

Gazetecilik dışı mesleki alanlara yönelimi maddi gerekçelerin yanı sıra Türkiye'de gazeteciliğin olumsuz koşulları belirlemektedir. Gazeteciliği şartlar nedeniyle değil de keyfi olarak yapmayan mezunların bu eğiliminde çoğunlukla yüksek maddi kazanç, hafif/ esnek/iyi çalışma koşulları, düzenli hayat ve kariyer gibi beklentiler rol oynamaktadır. Ancak gazetecilik dışı alanlara yönelenlerin daha iyi imkânlarda çalıştıklarını söylemek güçtür. Gazetecilikten uzaklaşırken birçok açıdan benzer ekonomik açmazlarla yüz yüze gelecekleri farklı iş kollarında istihdam olmaktadırlar.

Gazetecilik dışı alanlara yönelenlerin çoğu öncelikle özel sektörde işçi statüsünde çalışmakta, bu grubu işsiz mezunlar takip etmektedir. Sıralamada daha sonra da özel sektörde memur ya öğrenci statüsünü lisansüstü düzeyde devam ettiren mezunlar yer almaktadır. Gazetecilik dışı alandaki çalışanların dile getirdiği meslekler (fotoğrafçılık, grafik tasarımı, içerik üreticiliği vb.) gazetecilikle ya da alınan formasyonla bağlantılı gibi görünse de mahiyeti örtüşmemektedir. Örneğin fotoğrafçılık yaptığını söyleyenlerin çoğu, doğum fotoğrafçılığı ile ilgilenmektedir.

Araştırmada yaklaşık beşte bir oranında mezunun işsiz olduğu düşünülecek olursa, eğitim programlarındaki uygulamalı bazı derslerin (fotoğrafçılık, grafik tasarım vb) hep- 
ten işsiz kalmaktansa gazetecilik dışı ya da yan alanlarda iş bulmaya imkan sağladığını ve istihdamı artıracak pratik derslerin programlara daha fazla dahil edilmesi gerektiğini söylemek gerekir.

Mezunların çoğu sadece öğrencilik stajı sırasında mesleki pratiği deneyimlemektedir. Gazetecilik yapma konusundaki en önemli caydırıcı etken ise uzun süren işsizlik süreci ve yakın dönem konjonktürün meslek üzerindeki olumsuz etkileridir.

Özetle gazetecilik, mesleğin formasyonunu alanların zihinsel tasavvurunda belirli bir ideale karşılık gelmektedir. Öte yandan eğitim sürecinin, sektörün açmazları, ülke koşulları ve meslek üzerindeki baskılar bu tasavvurun idealize edilen yönünün halesini düşürmese de pratikte aynı değeri biçmeyi güçleştirmektedir. Ekonomik gerekçeler, mesleğe yönelenlerin de farklı yol seçenlerin de temel kıstasını oluşturmaktadır. Bu bağlamda, makro ve mikro etkenler bağlamında mesleki şartlarda olumlu yöndeki her değişikliğin gazetecilik mezunları için umut verici olacağı öngörülmektedir. Zira en hafifinden tasavvurlarındaki gazeteci kimliği ve mesleki ideal, bu umudu canlandıracak nüvelere sahiptir.

Çalışmanın başında da belirtildiği üzere, bu araştırma gündelik bir gözlemden yola çıkarak tasarlanmış ve uygulanmıştır. Gazetecilik formasyonu düşünüldüğünde mezunlarla ilgili çalışmalar kısmen göz ardı edilmekte, bu konudaki araştırmalar daha ziyade istihdam sorununu ele alan istatistik raporlarla sınırlı kalmaktadır. Oysa mezunlar üzerine yapılacak araştırmalar, öğrencilerin mezuniyet sonrası deneyimlerine göre gazetecilik eğitiminin gözden geçirilmesi ve revize edilmesi, eğitimi verilen formasyonun sektördeki istihdam karşılığının değerlendirilmesi, sektör deneyiminin niteliği ve sorunları hakkında bilgi sahibi olmak gibi pek çok konuda veri sağlayabilir. Veriler ilgili konuda revizyon amaçlı kullanılabilir. Bu çalışmanın bugüne dek gazetecilik mezunlarının istihdamına ilişkin araştırmalara bir boyut kazandıracağı umulmaktadır. Alan araştırmasında uygulanan anket soruları uyarlanarak ya da geliştirilerek, diğer iletişim fakültelerinin mezunlarına ilişkin profil çıkarılabilir, farklı analizlerle araştırma boyutlandırılabilir. Böylelikle gazetecilik ya da iletişim alanının mezun profiline ilişkin kapsamlı bir harita çıkarılabileceği gibi, sorunlara daha geniş bir çerçeveden çözüm aramak mümkün olabilir.

\section{Kaynaklar}

Altun, A. (1995). Türkiye'de Gazetecilik ve Gazeteciler. Ankara: ÇGD Yayınları.

Akgül, M. ve Akdağ, M. (2018). İletişim Eğitimi ve Disiplinlerarasılık: Illetişim Fakültelerindeki Akademisyen Profili Üzerine Bir Değerlendirme. Türkiye IIletişim Araştırmaları Dergisi. 31: s. $1-20$.

Atabek, G. Ş. ve Atabek, Ü. (2014). İletişim Eğitiminde Farklı Perspektifler: Öğrenciler, Akademisyenler ve Meslek Mensuplarının İletişim Eğitimi Hakkındaki Tutumları. Iletişim Kuram ve Araştırma Dergisi. (38): s. 148-163

Atabek, N., Ünlü, S. ve Taşçı, D. (2000). Anadolu Üniversitesi Illetişim Bilimleri Fakültesi Mezunlarının Mesleki Yaşamları Üzerine Bir Araştırma. Selçuk Iletişim Dergisi. 1 (2): s. 3-17.

Aydın, U.U. (2015). Lanetli Süreklilik/Neoliberal Militarizmden Otoriter Muhafazakarlığa Türk Medyasının Otuz Yılı. Uraz Aydın (der.) Neoliberal Muhafazakar Medya. İstanbul: Ayrıntı 
Yayınları. s. 31-65.

Bak, G. ve Eşidir, O.V. (2018). Gazetecilik Mesleğinde Çalışanların Çocuklarının Babasının Mesleklerine İlişkin Görüşleri. Journal Of Institute Of Economic Development And Social Research. 4 (15). s. 736-744.

Bayram, F. ve Arık, M. B. (2011). İletişim Eğitimi ve İletişim Akademisyenleri: Veriler Işı̆̆ında Bir Değerlendirme. Akdeniz Iletişim Dergisi. 15: s. 81-98.

Büyükaslan, A. ve Mavnacıoğlu, K. (2017). İletişim Fakültesi Ders Müfredatlarının Sektörün Nitelikli İşücü Talebine Uyumu. International Journal of Cultural and Social Studies (IntJCSS). 3(2): s. 219-233.

Büyükbaykal, G. ve Büyükbaykal, A.C.I. (2018). Türkiye'deki İletişim Fakültelerinde Eğitim ve Yaşanılan İstihdam Sorunları. Turkish Studies-Social Sciences. 13 (18): s. 321-334.

Çam, A. ve Yüksel, í. Ş. (2015). Türkiye'de Medyanın 2002 Sonrası Dönüşümü: Ekonomi-Politik Bir Yaklaşım. Uraz Aydın (der.) Neoliberal Muhafazakar Medya. İstanbul: Ayrıntı Yayınları. s. 66-102.

Dağdaş, E. (2011). Üniversite-Sanayi İşbirliği Perspektifinden Türkiye'deki Illetişim Eğitimine İlişkin Bir Değerlendirme. Akdeniz liletişim Dergisi. 15: s. 32-48.

Dirik, Ç. ve Çambay, S. (2019). Yeni Nesil Gazetecilik Eğitiminin Gazetecilik Bölümü Öğrencilerinin İş Bulma Avantajı Bağlamında Değerlendirilmesi. Turkish Studies-Social Sciences. 14 (1): s. 227-243.

Ergeç, N. E. (2014). Uluslar arası Yüksek Öğretim Trendleri Bağlamında İletişim Eğitimini Yeniden Düşünmek. Selçuk Iletişim Dergisi. 8 (2): s. 5-31.

Ezber, B. ve Sayar, T. E. (2016). Türkiye'de Akademi Dışı Medya ve İletişim Eğitimi. Marmara IIletişim Dergisi. 26: s. 71-83.

Geray, H. (2014). Iletişim Alanından Örneklerle Toplumsal Araştırmalarda Nicel ve Nitel Yöntemlere Giriş. Kocaeli: Umuttepe Yayınları.

Güz, N., Yanık, H. ve Yeğen, C. (2017). İletişim Fakülteleri Eğitim Sistemine Yönelik Yeni Bir Yaklaşım. International Journal of Social Sciences and Education Research. 3 (5): s. $1546-$ 1560.

Kandemir, C. (2012). Türkiye'de ve Almanya'da Gazetecilik Eğitimi Alan Öğrencilerin Eğitim Kalitesi ve Beklentilerine Yönelik Alan Araşıırması. İstanbul Üniversitesi Iletişim Fakültesi Dergisi. 30: s. 97-112.

Karaarslan, İ. A. (2019). Gazetecilik Eğitimin Dijitalleşmesi: Gelişmiş ve Gelişmekte Olan Ülkeler Üzerinde Yapılan Karşılaştırmalı Analiz. Erciyes Illetişim Dergisi. 1: s. 105-124.

Karaduman, M. ve Akbulutgiller, B. (2017). Türkiye'de Gazetecilik Eğitimi: Lisans Müfredat Programları Karşılaştırması. Gaziantep University Journal of Social Sciences. 16 (4): s. 11611181.

Karatabanoğlu, S. (2019). Yurtdışında Gazetecilik: Avantajları ve Dezavantajları. 20.08.2019 tarihinde https://journo.com.tr/yurt-disinda-gazeteci-olmak adresinden edinilmiştir.

Korkmaz, A. (2012). Gazetecilik Eğitimi Alan Öğrencilerin Gazetecilik Eğitimi ve Gazetecilik Mesleğine Bakışı. Akdeniz Illetişim Dergisi. 16: s. 9-27.

Mavioğlu, E. (2014). Monarşiden Bugüne Türkiye Medyasında Baskı ve Sansür: AKP İktidarı ve Yeni Medya Karteli. Esra Arsan ve Savaş Çoban (der.) Medya ve Iktidar-Hegemonya, Statüko, Direniş- İstanbul: Evrensel Kültür Kitaplığı. s. 137-152.

Narin, B. (2018). Dünyada Akademik Sıralaması Yüksek Gazetecilik Lisans Bölümlerinin Ders 
Programlarının Analizi. Iletişim Kuram ve Araştırma Dergisi. (47): s. 87-110.

Narin, E. (2019). Gazetecilik Mezunları Mesleklerini Yapamıyor. 07.08.2019 tarihinde http:// media4democracy.org/news/gazetecilik-mezunlari-mesleklerini-yapamiyor adresinden edinilmiştir.

Öke, M. K. (1994). Gazeteci: Türkiye'de Basın Çalışanları Üzerine Bir İnceleme. Ankara: ÇGD Yayınları.

Öztürk, S. (2011). İletişim Eğitiminin Hedefi: Yeni Bir Entelektüel Yaratmak. Akdeniz Illetişim Dergisi. 15: s. 145-156.

Öztürk, Ş. (2017). Türkiye'de Gazetecilerin Çalışma Sorunları. Kırklareli Üniversitesi Iktisadi ve Idari Bilimler Fakültesi Dergisi. 6 (1): s. 89-111.

Seçkin, G. (2010). 2000 Yılında Türkiye'de Gazetecilerin Ekonomik ve Sosyal Statüsü. Global Media Journal. 1 (1): s. 48-109.

Sönmez, M. (2014). Dünden Bugüne Türkiye'de Medyanın Ekonomi Politiği. Esra Arsan ve Savaş Çoban (der.) Medya ve Iktidar -Hegemonya, Statüko, Direniş- İstanbul: Evrensel Kültür Kitaplığı. s. 86-102.

Sözeri, C. (2014). Dönüşen Medya Değişmeyen Sorunlar. Esra Arsan ve Savaş Çoban (der.) Medya ve İktidar -Hegemonya, Statüko, Direniş- İstanbul: Evrensel Kültür Kitaplığı. s. 70-85.

Şeker, M. ve Şeker, T. (2011). İletişim Eğitiminde Temel Sorunlar ve Açmazlar. Akdeniz Iletişim Dergisi. 15: s. 99-118.

Temel, F. ve Önürmen, O. (2017). Gelenekselin Dönüşümünde İletişim Akademisyenleri ve Sosyal Medya. Gümüşhane Üniversitesi Illetişim Fakültesi E-Dergisi (e-gifder). 5 (1): s. 292-313.

Tokgöz, O. (2003). Türkiye'de İletişim Eğitimi: Elli Yıllık Bir Geçmişin Değerlendirilmesi. Kültür ve Illetişim. 6 (1): s. 9-32.

Tokgöz, O. (2006). Türkiye'de İletişim Araştırmalarında İletişim Eğitimin Rolü ve Önemi. Küresel iletişim Dergisi. (1): s. 1-12.

TÜRK-iŞ (2017). Türkiye'de Açlık ve Yoksulluk Sınırı Ne Kadar Oldu?. 20.06.2019 tarihinde http://www.turkis.org.tr/MAYIS-2017--ACLIK-ve-YOKSULLUK-SINIRI-d3506 adresinden edinilmiştir.

Uçak, O. (2011). Medyada Fikir İşçilerine Tanınan Haklar Süreci Ve Karşılaştırmalı Uygulama Örnekleri, III. Sosyal Haklar Uluslararası Sempozyumu Bildiriler Kitabı. Kocaeli: Petrol-iş̧ Yayınları. ss. 383-400.

Uzun, R. (2007). İstihdam Sorunu Bağlamında Türkiye'de İletişim Eğitimi ve Öğrenci Yerleştirme. Iletişim Kuram ve Araştırma Dergisi. (25): s. 117-134.

Uzun, R. (2011). Türkiye'de Gazetecilik Eğitimi: Değişimler ve Eğilimler. Akdeniz Iletişim Dergisi. (15): s.119-132.

Yanatma, S. (2018). Digital News Report 2018-Turkey Supplementary Report. 28.08.2019 tarihinde https://reutersinstitute.politics.ox.ac.uk/our-research/digital-news-report-2018-turkeysupplementary-report adresinden edinilmiştir.

Yıldırım, B. (2006). Eleştirel Pedagoji Açısından Gazetecilik Eğitimini Yeniden Düşünmek. Iletişim Araştırmaları Dergisi. 4 (1): s. 121-152.

Yıldırım, B. (2012). Dünyada ve Türkiye'de Gazetecilik Eğitimi: Kısa Bir Kurumsallaşma Tarihi. Ömer Özer (ed.). Haberin Doğası: Gazetecilikte Idealler ve Sorunlar. Konya: Literatürk Yayınları. s. 413-464. 
Yıldııım, B. (2016). Iletişim/Gazetecilik Eğitiminde İnsan Hakları. A. N. Yıldız Tahincioğlu (ed.). Yamuk Hakikat. Ankara: Ütopya Yayınları. s. 111-151.

Özbek, M. (1992). İletişim Eğitimi Üzerine. ILEF YILLIK. s. 307-328.

Akgül, H., Akgül, B. ve Ayer, Z. (2018). Sanayi 4.0 Sürecinde Gazetecilik Eğitim Programı Oluşturmada Yeni Yaklaşımlar. Avrupa Sosyal ve Ekonomi Araştırmaları Dergisi. 5 (8): s. 190197.

Gezgin, S. (2005). Türkiye'de Gazetecilik Eğitimi. 25.05.2019 tarihinde http://www.konrad.org.tr/ Medya\%20tr/10suat.pdf adresinden edinilmiştir.

DiSK-AR. (2018). 06.08.2019 tarihinde http://disk.org.tr/2018/05/disk-ar-issizlik-raporu-mayis2018-her-bes-gencten-biri-issiz/ adresinden edinilmiştir.

Yanatma, S. (2019). Digital News Report-Turkey. 28.08.2019 tarihinde http://www. digitalnewsreport.org/survey/2019/turkey-2019/ adresinden edinilmiştir.

https://www.anketcozumu.com/orneklem-hesaplama/ , 05.11.2019 tarihinde erişim sağlanmıştır. 